\title{
O homem entediado: \\ niilismo e técnica no pensamento \\ de Martin Heidegger
}

Prof. Dr. Marco Antonio Casanova

O presente artigo é fruto da lisonjeira tarefa de homenagear Benedito Nunes, este que foi durante todo o tempo um verdadeiro desbravador de caminhos para todos nós. Seguir por estes caminhos, levar adiante os questionamentos feitos por Benedito, seguir a possibilidade de tomar a filosofia de Martin Heidegger em sua inteireza e fazer dela um horizonte de articulação possível para a vida do próprio pensar, são os objetivos que guiam o presente ensaio. Assim pretendemos questionar a essência do acontecimento do tempo que é o nosso, nitidamente marcado por fenômenos que obtêm papel central na obra de Heidegger e que são exemplarmente discutidos por Benedito Nunes em seus diversos ensaios, conferências, livros, críticas e intervenções: o niilismo, a técnica e o tédio profundo, tonalidade afetiva fundamental de nosso filosofar atual. Nosso confronto com a filosofia de Nietzsche é imprescindível na tentativa de interpelar tais fenômenos, assim como o foi para o próprio Heidegger e para Benedito Nunes, a quem este texto é dedicado, com o respeito às preciosas contribuições e o reconhecimento da vida filosófica que construiu com a coerência inflexível de todo o seu destino pessoal autêntico.

PALAVRAS-CHAVE niilismo, vontade de poder, metafísica, técnica

The present article is the result of the flattering task of honoring Benedito Nunes, who was during all times a true pathfinder for us all. Follow these paths, carry out the quetionings made by Benedito, follow the possibility of taking Martin Heidegger's philosophy in its entirety and make it a possible horizon of articulation for the life of the thinking itself are the goals that guide the present essay. So we intend to question the essence of the happening of time that is ours, clearly marked by phenomena that takes central role in Heidegger's work and are admirably discussed by Benedito Nunes in his various essays, lectures, books, reviews and interventions: nihilism, technique and profound boredom, fundamental affective tone of our philosophy today. Our confrontation with Nietzsche's philosophy is indispensable in an attempt to interpellate such phenomena, as it was for Heidegger and Benedito Nunes, whom this text is dedicated, with respect to the precious contributions and recognition of the philosophical life he built with inflexible consistency of all his authentic personal destiny.

KEY-WORDS nihilism, will to power, metaphysic, technical. 
O homem entediado: niilismo e técnica no pensamento de Martin Heidegger
Prof. Dr. Marco Antonio Casanova

" $O$ andarilho sem destino reparou então/ que seus sapatos tinham a poeira indiferentel de todas as pátrias pitorescas; e que seus olhos conservavam as noites e os dias/dos climas mais vários do universo;/ e que suas mãos se agitaram em adeuses/ a milhares de cais sem saudades e amigos;/ e que todo o seu corpo tinha conhecido/ as mil mulheres que Salomão deixou./ E o andarilho sem destino viu/ que não conhecia a Tarde que está oculta no tempo/ sem paisagens terrenas, sem turismo, sem povos,/ mas com a vastidão infinita onde os horizontes/ são as nuvens que fogem".

- Jorge de Lima, "Tarde oculta no tempo", em: Tempo e Eternidade -

"A primeira e única evidência que assim me é dada, no âmbito da experiência absurda, é a revolta. Privado de qualquer conhecimento, impelido a matar ou a consentir que se mate, só disponho dessa evidência que é reforçada pelo dilaceramento em que me encontro. A revolta nasce do espetáculo da desrazão diante de uma condição injusta e incompreensivel".

- Albert Camus, O homem revoltado, p. 21 - 
Ao receber o convite extremamente lisonjeiro para escrever um artigo em homenagem ao professor Benedito Nunes, uma questão surgiu imediatamente para mim: como homenagear de modo próprio uma pessoa que desempenhou um papel tão decisivo na determinação específica de meu caminho na filosofia? Como homenagear a vida filosófica que se construiu com a coerência inflexível de todo destino pessoal autêntico em tantos ensaios, conferências, livros, críticas e intervenções? Como resgatar em um texto a serenidade tranquila e o caráter acolhedor de toda a presença de Benedito? O texto que agora se inicia é uma tentativa de fazer frente a estas questões. Para tanto, procurei escolher, em primeiro lugar, um tema que acenasse para o início de meu caminho tanto quanto para o livro que me abriu originariamente um horizonte novo e alvissareiro na filosofia. Lembro-me muito bem do impacto provocado pela leitura que fiz ainda calouro da faculdade de filosofia da Universidade Federal do Rio de Janeiro do livro Passagem para o poético: filosofia e poesia em Heidegger. O livro apresenta de maneira clara e exaustiva a essência estrutural de Ser e tempo e o momento de transição dessa obra capital do pensamento heideggeriano para as reflexões tardias sobre arte, poesia e linguagem. Neste sentido, ele abre uma possibilidade de apreender a unidade estrutural da obra de Heidegger, sem ao mesmo tempo impor de maneira desnecessária uma periodização artificial. Ao mesmo tempo, o livro é repleto de um estilo solar, de uma vivacidade intelectual única, de um domínio extremo dos verdadeiros problemas: tudo isto me fez imediatamente perceber a possibilidade de um trabalho vigoroso e preciso em torno do pensamento de Martin Heidegger. Não para compreendê-lo apenas em suas minúcias, mas para encontrar nele um horizonte de articulação possível para a vida do próprio pensar. Em segundo lugar, exatamente pela riqueza do trabalho de Benedito Nunes, não me pareceu fazer sentido permanecer apenas no âmbito do pensamento heideggeriano. Era indispensável resgatar de algum modo ao menos a presença de um outro pensador com o qual Benedito incessantemente dialogou, seja por conta de sua importância para a relação entre poesia e filosofia, seja pela posição no interior da própria obra de Heidegger: Friedrich Nietzsche. Por fim, não pude deixar de me ver tentado a acompanhar um elemento presente em muitos textos de Benedito. De maneira tão frequente quanto trata especificamente da poesia, Benedito se volta também para aquele fenômeno, para aquela experiência do homem contemporâneo, que entrega à poesia um lugar decisivo no mundo que é o nosso: o fenômeno do niilismo. Mais ainda, sua confrontação pensante com Nietzsche e Heidegger dá voz ao fato de esses dois pensadores terem visto desde o princípio com clareza o niilismo como o tema de nosso tempo. Escrevendo sobre Nietzsche, Heidegger e niilismo, estou, assim, ao mesmo tempo homenageando o diálogo no qual Benedito soube como ninguém se inscrever. Um diálogo que faço meu com o facho de luz lançado por quem se fez e se faz incessantemente desbravador de caminhos. 


\section{Introdução}

O mundo contemporâneo é com certeza marcado por estruturas maximamente diversas que constantemente intensificam a sua complexidade. A expansão extrema dos espaços destinados aos processos de produção, o incremento substancial dos níveis médios de subsistência promovido pelos sucessivos avanços tecnológicos, a ampliação do corpo sociopolítico das comunidades em geral, a extensão das malhas de poder e controle a um nível simplesmente descomunal trouxeram consigo redes difusas de relações cada vez mais intensamente ramificadas, que sempre se conectam com outras tantas redes congêneres. O que costumamos chamar de sociedade pós-industrial aponta antes de mais nada para um conjunto em princípio inabarcável de formas de vida dotadas de um sem número de peculiaridades impassíveis de serem absorvidas em unidades homogêneas superiores. Diante do mundo contemporâneo sentimo-nos muitas vezes como o náufrago perdido e solitário em alto-mar, sem qualquer possibilidade de encontrar um apoio ainda que precário para suportar as ondas incessantes do mar imenso. Em suma: se a filosofia realmente nos salvou um dia "da imaginação selvagem e infinitamente colorida de Homero"1, parecemos hoje entregues uma vez mais à força descomunal da multiplicidade. Levando esse estado de coisas em consideração, é bem provável que o intuito essencial do presente texto provoque a princípio alguma estranheza. O que pretendemos aqui é antes de mais nada tratar de um traço distintivo do homem contemporâneo, de uma tonalidade afetiva fundamental que o transpassa radicalmente em todas as suas ações e possibilidades existenciais em geral. O que buscamos é, em outras palavras, justamente escapar da dispersão no universo multiforme e multicolorido característico do mundo contemporâneo, a fim de encontrar em meio a esse universo algo como o seu mobilizador estrutural. Essa tarefa requer, por sua vez, uma demarcação inicial do lugar em que nos encontramos, da facticidade do tempo ao qual pertencemos, do projeto existencial no qual já sempre nos movimentamos. Nós perguntamos, então: quais são as marcas distintivas de um tal projeto existencial? Em que medida é possível descrever filosoficamente o conteúdo próprio à nossa facticidade? Qual a relação entre esse projeto e essa facticidade, por um lado, e, por outro lado, a tonalidade afetiva fundamental do tédio mencionada no título de nosso texto? Essas são questões que encontram um tratamento paradigmático no interior do pensamento de Martin Heidegger: mais especificamente, em sua concepção do fenômeno do niilismo e da articu-

1 G. W. F. Hegel, Preleções sobre a história da filosofia 1, “Tales". Passagem citada a partir do texto Pré-socráticos (Os pensadores), Vol. 1, p. 36. 
lação dessa concepção com a essência da técnica moderna. Assim, é em diálogo direto com a obra de Heidegger que nos conduziremos aqui.

\section{O conceito heideggeriano de niilismo: abandono do ser e metafísica da vontade de poder e do eterno retorno do mesmo em Nietzsche}

É importante notar algumas coisas antes de tematizar diretamente o conceito heideggeriano de niilismo. Em primeiro lugar, é preciso ressaltar inicialmente o fato de Heidegger não tomar o fenômeno do niilismo como um fenômeno cultural ou social qualquer, que veio à tona de maneira contingente em um determinado momento do tempo a partir da confluência de um certo conjunto de fatores materialmente descritíveis e historiologicamente fixáveis. $\mathrm{O}$ termo niilismo não é pensado por ele como algo que precisa ser analisado a partir de uma certa crítica social ou cultural. Ao contrário, Heidegger o considera desde o princípio como o ponto de culminação do próprio movimento histórico de nossa tradição e como um fenômeno articulado com o que essa tradição possui de aparentemente mais positivo. Niilismo é aqui o nome para a consumação de um determinado processo histórico e para a medida plenamente concretizada no fim desse processo. Dito de maneira mais explícita: é a própria metafísica que se mostra para Heidegger como niilismo e que encerra em si mesma desde o seu despontar mais primordial a essência desse fenômeno. Em segundo lugar, também não podemos perder de vista o fato de Heidegger possuir um entendimento deveras peculiar da história, o que impede uma série de conclusões apressadas relativas a um alijamento definitivo do niilismo e da metafísica. Heidegger não concebe a história como o âmbito de realização de um conjunto específico de eventos do passado que produzem transformações da vida e da cultura humanas e que são por assim dizer causados mecanicamente no tempo concebido como algo presente-à-vista. ${ }^{2}$ Ele a compreende muito mais como o horizonte de constituição de certos acontecimentos intrinsecamente articulados com possibilidades fundamentais retidas naquilo que um dia se deu de modo tão essencial que nunca chegou efetivamente a se perder no passado e que sempre continua viabilizando a cada vez no instante uma decisão quanto ao modo

2 Cf. nesse sentido, Ser e tempo, § 73, GA 2, p. 498: “A análise da historicidade do ser-aí procura mostrar que esse ente não é 'temporal' porque 'se encontra na história', mas que só existe e pode existir inversamente de maneira histórica porque é no fundo de seu ser temporal'. 
de ser daquilo que está por vir. ${ }^{3}$ Como Heidegger mesmo afirma em sua preleção do semestre de verão de 1943 sobre Heráclito:

Uma coisa é produzir historiograficamente uma imagem do passado para o respectivo presente, uma outra é pensar historicamente, isto é, experimentar o que foi e continua sendo (das Gewesene) como o porvir (das Künftige) que já está se essencializando. Todos os renascimentos apenas historiológicos do passado não passam de más fachadas para equívocos históricos. (H, GA 55, 11)

A compreensão heideggeriana da história repousa, portanto, sobre uma vinculação dos desdobramentos possíveis do instante presente e do porvir a determinados acontecimentos que traçam desde o princípio os limites no interior dos quais tanto o instante quanto o porvir respectivamente se dão. $\mathrm{O}$ instante $\mathrm{e}$ o porvir encontram-se aqui sob o domínio incontornável de seu próprio princípio. ${ }^{5}$ Desse modo, é preciso ler o processo histórico em questão no pensamento heideggeriano a partir não de posições particulares em relação a determinados eventos que se deram no passado e que condicionaram em muito os desdobramentos ulteriores da história, mas inversamente a partir de um determinado conjunto de acontecimentos que se acham articulados com decisões denominadas por ele históricas. Esses acontecimentos apontam, por sua vez, para expressões como compreensão de ser, abertura do ser do ente na totalidade ou essenciação da verdade do ser, porque o que está em jogo com eles não são os comportamentos dos seres-aí humanos em relação aos entes intramundanos,

3 Não é difícil perceber nessa formulação uma proximidade com a concepção nietzschiana de uma "história a serviço da vida", tal como essa concepção se encontra desenvolvida na Segunda consideração Intempestiva: Da utilidade e da desvantagem da história para a vida Cf. quanto a essa concepção M.A.Casanova, $O$ instante extraordinário: vida, história e valor na obra de Friedrich Nietzsche, Rio de Janeiro, Forense Universitária, 2003.

4 Cf. também Martin Heidegger, Die Grundfragen der Philosophie, GA 45, p. 40: "O historiológico significa, como a palavra deve indicar, aquilo que passou, na medida em que é pesquisado e representado a partir do respectivo campo de visão do presente respectivo - seja expressa ou inexpressamente. Toda consideração historiológica transforma o passado em objeto. (...) O histórico não tem em vista o modo da apreensão e pesquisa, mas o próprio acontecimento. O histórico não é aquilo que passou, nem tampouco o atual, mas o porvir que é colocado na vontade, na expectativa, no cuidado".

5 Quanto a esse domínio daquilo que foi essencial ao pensamento de Heidegger, cf. R. Bernasconi, The question of language in Heidegger's history of being, New Jersey, Humanities Press International, 1989; M.Haar, Heidegger e a essência do homem, trad. A.Alves, Lisboa, Instituto Piaget, 1990. 
aos outros seres-aí e a si mesmo, mas antes a medida mesma de todos esses comportamentos, o horizonte fenomenológico de sua própria constituição e manifestação ${ }^{6}$. Nesse sentido, investigar o niilismo como ponto de culminação de nosso processo histórico implica trazer simultaneamente à tona a compreensão de ser ou a determinação do ser do ente na totalidade imersa desde o princípio em seu horizonte de instauração. No que concerne a essa tarefa, uma formulação presente na preleção do semestre de inverno de 1937/38 sobre Die Grundfrage der Philosophie (As questões fundamentais da filosofia) fornece-nos uma indicação inicial. Heidegger diz aí:

O abandono do ser em relação ao ente é o fundamento mais velado e mais próprio daquilo que Nietzsche reconheceu pela primeira vez como 'niilismo' e concebeu a partir da 'moral', do 'ideal', de maneira platônico-schopenhaueriana, mas ainda não metafisicamente.

(GFP, GA 45, 185-6) $)^{7}$ (BP, GA 65, 140-41)

Essa pequena passagem revela dois elementos centrais da concepção heideggeriana do niilismo. Em primeiro lugar, ela contém uma definição formal do próprio conceito de niilismo: para Heidegger, niilismo não é outra coisa senão "abandono do ser". Em segundo lugar, ela nos coloca imediatamente em contato com o horizonte a partir do qual Heidegger desenvolve a princípio a sua concepção do niilismo: o horizonte de uma confrontação direta com o pensamento

6 Não tenho como analisar aqui mais detidamente esse ponto. No entanto, não é difícil reconstruir resumidamente o argumento central de Heidegger. Para que o ser-aí possa se comportar em relação aos entes que vêm ao seu encontro, é preciso que haja um horizonte de manifestação desses entes. Esse horizonte de manifestação não pode ser alcançado pela mera extensão de conteúdo dos campos ônticos em geral porque ele já sempre precisa estar presente para que os campos ônticos possam se constituir e porque toda extensão desses campos sempre acaba por projetar o horizonte de sua manifestação para além de si mesmos. Dessa forma, ele já precisa estar desde o princípio presente em meio a todo comportamento do ser-aí e precisa transcender incessantemente qualquer tentativa de alcançar o conjunto maximamente extenso dos entes que se mostram a partir desse horizonte. Os comportamentos do ser-aí pautam-se, por sua vez, pelas respectivas determinações ontológicas dos entes: eu lido com um ente sempre a partir de seu modo de ser enquanto utensílio, ente presente-à-vista, ente natural, entidade matemática etc. $\mathrm{O}$ horizonte de manifestação dos entes em geral não pode ser, com isso, senão a determinação do ser do ente na totalidade. Cf. mais detidamente quanto a isso M. Heidegger, Introdução à filosofia, trad. M.A.Casanova, São Paulo, Martins Fontes, 2009. Cf. também J. Sallis, Echoes after Heidegger, Bloomington and Indianapolis, Indiana University Press, 1990; e D. Dahlstrom, Heidegger's Deliberations, em Research in Phenomenology 30 (1), 2000, pp.254-259.

7 M.Heidegger, Grundfragen der Philosophie, em Gesamtausgabe, op.cit., vol. 45, pp. 1856; Cf. também M.Heidegger, Beiträge zur Philosophie (Vom Ereignis), em Gesamtausgabe, op.cit., vol. 65, pp. 140-41. 
de Nietzsche. Para uma interpretação adequada da concepção heideggeriana do niilismo, é extremamente importante diferenciar antes de mais nada o conceito de niilismo em Heidegger daquele estabelecido por Nietzsche, porque Heidegger compreende a própria filosofia nietzschiana como o "derradeiro enredamento no niilismo" e como a "consumação do próprio niilismo" e porque ele transforma, assim, a filosofia nietzschiana em momento de sua compreensão da história da metafísica como história do niilismo. Mas o que Nietzsche compreende, afinal, por niilismo? Em que medida essa compreensão pode se confundir com o derradeiro enredamento no niilismo?

Como se sabe, Nietzsche dedicou-se enormemente a uma tematização do niilismo em seus últimos cadernos póstumos. Nesses textos, niilismo é um termo usado para descrever fundamentalmente o fenômeno que surge a partir do declínio do modo metafísico de interpretação do mundo. Essa determinação conceitual está, por sua vez, em conexão essencial com a compreensão nietzschiana da metafísica ${ }^{9}$. Para Nietzsche, a metafísica é caracterizada pelo fato de cindir originariamente o mundo em dois âmbitos estruturais e tomar ao mesmo tempo um desses âmbitos como critério ontológico de avaliação do outro. Metafísica é, segundo ele, um saber que trabalha incessantemente com dicotomias e sempre gera essas dicotomias a partir de um juízo de valor originário em relação à existência como um todo. Pressupõe-se, nesse caso, que o conhecimento verdadeiro e a ação moralmente justificada são impossíveis no interior do devir e do mundo da aparência, de modo que não se considera necessário apenas liberar a verdade e o bem de todo contato com eles, mas também se assume a verdade e o bem como a única realidade efetiva ${ }^{10}$. Desse modo, a metafísica vem à tona como um saber que separa absolutamente ser e devir (aparência) e que apresenta o âmbito do ser como o único verdadeiro. Toda a existência é, com isso, erigida em função de uma transcendência assim autonomizada e só alcança um sentido por meio daí. No entanto, uma vez que o projeto metafísico da fundamentação última e absoluta da transcendência fracassa, o mundo como um todo parece repentinamente sem sentido.

8 M.Heidegger, Metaphysik und Nihilismus, em Gesamtausgabe, op.cit., vol. 67, p.208.

9 Quanto a esse conceito cf. M.A.Casanova, O instante extraordinário: vida, história e valor na obra de Friedrich Nietzsche, op.cit., especialmente o terceiro capítulo que trata justamente da relação entre metafísica e niilismo.

10 Comparar com Aristoteles De coelo, III, 1, 298b23: “(...) sem a existência de substâncias imóveis não pode haver nem conhecimento teórico (episteme) nem saber prático (phronesis)". Quanto à diferença entre o conceito heideggeriano e nietzschiano de metafísica, cf. M.Haar, Nietzsche et la métaphysique, Paris, Gallimard, 1993; e W. Müller-Lauter, Nietzsche Interpretationen III: Nietzsche und Heidegger, Berlin, De Gruyther, 2000. 
O sentimento da ausência total de valor foi atingido quando se compreendeu que o caráter conjunto da existência não pode ser interpretado nem com o conceito de 'meta', nem com o conceito de 'unidade', nem com o conceito de 'verdade'. Com isso, nada é obtido e alcançado; falta a unidade abrangente na pluralidade do acontecimento: o caráter da existência não é 'verdadeiro', é falso... não temos mais simplesmente nenhuma razão para nos convencermos de um mundo verdadeiro... Em resumo: as categorias de 'meta', 'unidade', 'ser' com as quais nos acostumamos a dar um valor ao mundo, foram uma vez mais retiradas por nós - e agora o mundo parece desprovido de valor... ${ }^{11}$

De acordo com a concepção nietzschiana, portanto, o niilismo confunde-se com um tal sentimento de ausência de valor ou de sentido do mundo. Ele consiste em uma desvalorização dos valores supremos até aqui, uma vez que esses valores funcionaram durante toda a história do Ocidente como as categorias centrais para a interpretação do mundo e uma vez que o fato de eles terem se tornado agora insustentáveis produziu uma sensação de perda radical de sentido para o mundo. Frente a essa compreensão do niilismo apresentada aqui de maneira deveras sucinta, precisamos perguntar: em que medida uma filosofia que tem uma tal compreensão do niilismo pode ser o "derradeiro enredamento no niilismo"? O que existe aí propriamente de niilismo? Como o próprio Heidegger determina esse conceito, para que o pensamento nietzschiano possa se mostrar ele mesmo como a consumação do niilismo da tradição?

Tal como vimos anteriormente, o conceito heideggeriano de niilismo aponta para a expressão "abandono do ser": não é senão como abandono do ser que Heidegger compreende a essência do niilismo contemporâneo. No que diz respeito a essa expressão, não é difícil reconstruir em seus traços fundamentais o que Heidegger tem em vista com ela. De maneira bastante sintética, podemos dizer: abandono do ser é uma expressão que designa o surgimento de uma determinada abertura do ente na totalidade (um mundo), na qual o ser abandona tão radicalmente o ente que esse parece vigorar como a única instância real ${ }^{12}$.

11 NIETZSCHE, F. W. Sämtliche Werke. Kritische Studienausgabe. G. Colli und M. Montinari (Hg). Berlin: Walter de Gryter, 1999. 15 Bd. V. 11(99) 48. Novembro de 1887-Março de 1888.

12 Cf. quanto a esse ponto Martin Heidegger, Beiträge zur Philosophie (Vom Ereignis), em 
Ele aponta para a redução de todas as possibilidades da existência ao plano ôntico, ao âmbito do aparecimento e desaparecimento de configurações complexas de duração relativa de vida no interior do deviri ${ }^{13}$, ao âmbito no qual acaba por se instaurar uma lida estratégica calculável com todas configurações do real e no qual o ser ele mesmo nunca se acha em questão. Essa lida não é por sua vez condicionada pelo círculo inteiramente privado das resoluções arbitrárias e subjetivas do indivíduo, mas antes pelo surgimento de estruturas fundamentais que nascem juntamente com o mundo do abandono do ser. Com isso, abandono do ser é uma expressão que descreve um esquecimento radical da constelação originária entre ser e ser-aí humano e a consequente imersão total do homem no mundo dos entes. Se não é por um lado inicialmente difícil reconstruir o conceito de niilismo como abandono do ser, é somente uma análise acurada de tais estruturas fundamentais que pode, por outro lado, propiciar uma compreensão efetiva desse conceito. Em outras palavras, nós precisamos descrever como o abandono do ser se torna operativo no mundo contemporâneo, o que acontece propriamente quando o ser abandona o ente e quais são efetivamente as estruturas que condicionam a absolutização do plano ôntico. Essa descrição acha-se em ressonância direta com a interpretação heideggeriana do pensamento de Nietzsche.

Segundo a compreensão nietzschiana, o niilismo repousa sobre a desvalorização dos valores supremos até aqui. Essa desvalorização provém essencialmente da dissolução da cisão metafísica primordial entre mundo sensível e mundo suprassensível e da consequente redução da totalidade ao mundo "sensível", ao único mundo que realmente há e que, por isso, não pode continuar sendo chamado nem mesmo de sensível. Na medida em que uma tal dissolução tem lugar, perde-se imediatamente, é isso que nos diz Heidegger, toda e qualquer ligação com o pensamento do ser e o ser mesmo se transforma em nada. A pergunta sobre o ser, que tinha constituído outrora "o começo de nossa filosofia científica" ${ }^{14}$ em Platão e Aristóteles, desaparece pura e simplesmente em meio à sua assunção como sem sentido, de modo que o ente passa a dominar sozinho todo o espaço de abertura. De acordo com a interpretação heideggeriana, portanto, a filosofia de Nietzsche daria ensejo ao surgimento do tempo do do-

Gesamtausgabe, op.cit., vol. 65, p. 445: É necessário “(...) reconhecer no não-ocupar-se com o seer um estado necessário no qual se esconde um estágio insigne da história do próprio seer. A partir desse evento de todos o mais indiferente no interior das coisas que se dão hoje, é preciso ouvir o eco do acontecimento apropriativo decisivo."

13 NIETZSCHE, F. W. Sämtliche Werke. Kritische Studienausgabe. G. Colli und M. Montinari (Hg). Berlin: Walter de Gryter, 1999. 15 Bd. V. 11(73) 36. Novembro de 1887-Março de 1888.

14 M. Heidegger, Heraklit. 1.Der Anfang des abendländischen Denkens, em Gesamtausgabe,op. cit., vol. 55, 1979, p. 184. 
mínio absoluto do ente sobre o ser e do respectivo abandono do ser. Esse estado de coisas encontra por sua vez um ponto de sustentação adequado na análise empreendida por Heidegger de duas noções fundamentais do pensamento de Nietzsche: vontade de poder e eterno retorno do mesmo. Mas como Heidegger entende o conceito nietzschiano de vontade de poder? Em que medida esse conceito se articula com o pensamento do eterno retorno do mesmo? Até que ponto essa articulação abre o caminho para um tal domínio incondicionado do ente sobre o ser?

Segundo Heidegger, a "vontade de poder é a 'essência' do ente enquanto tal ${ }^{15}$. Desse modo, a vontade de poder se mostra aqui como a resposta nietzschiana para a pergunta tradicional metafísica: o que é o ente enquanto tal ou o ser do ente em geral. Todavia, o que Heidegger tem em vista com essa afirmação não se confunde com uma compreensão da vontade de poder enquanto uma espécie de princípio substancial metafísico, ao qual a realidade como um todo poderia ser reduzido. Ao contrário, Heidegger tem desde o início clareza quanto ao fato de a vontade de poder não se mostrar como uma espécie de em si da realidade, mas antes muito mais como o modo e a lei de estruturação de todas as configurações possíveis da totalidade. Não há nenhuma dúvida para ele de que "Nietzsche quer o devir e o que vem a ser como o caráter fundamental do ente na totalidade." 16 No entanto, estabelecer o devir como o caráter fundamental do ente na totalidade significa imediatamente "querer o devir precisamente e antes de qualquer coisa como o que permanece - como o 'ente' propriamente dito" e "sendo justamente no sentido dos pensadores gregos." sa a ser, então, saber como a vontade de poder pode se mostrar como um tal elemento constante. Para tanto, é fundamental escutar a própria caracterização heideggeriana da vontade de poder. Heidegger diz em uma pequena passagem do segundo volume de suas preleções sobre Nietzsche: O poder não é a meta, em direção à qual a vontade se encaminha volitivamente como em direção a algo fora de si mesma. A vontade não aspira ao poder, mas já se essencializa sempre e apenas na esfera essencial do poder. Não obstante, a vontade não é simplesmente poder e o poder também não é simplesmente vontade. Ao invés disso, o que temos é muito mais o seguinte: a essência do poder é vontade de poder e a essência da vontade é vontade de poder. Somente a partir desse saber da essência, Nietzsche pode dizer ao invés de 'vontade' também 'poder' e ao

15 M.Heidegger, A sentença nietzschiana "Deus está morto", em Caminhos da Floresta, Gesamtausgabe, op.cit., vol. 5, p. 242.

16 M.Heidegger, Nietzsche I, em Gesamtausgabe, op.cit., vol. 6.1, p. 592.

17 Ibid 
invés de 'poder' também 'vontade'. Isso, contudo, não implica absolutamente uma equiparação entre vontade e poder (...). A expressão 'vontade de poder' deve designar justamente a simplicidade indissociável de uma essência única e composta: a essência do poder.

O poder só se realiza como poder, na medida em que se torna senhor sobre o estágio de poder a cada vez alcançado. O poder só é e só permanece como poder, quando permanece elevação de poder e comanda o mais em meio ao poder. Já a mera contenção em meio a uma elevação de poder, o estagnar-se em um estágio de poder, instaura o começo da impotência. À essência do poder pertence a super-dominação de si mesmo. Essa emerge do próprio poder, porquanto ele é comando e como comando dota a si mesmo de poder para a super-dominação: dominação do estágio de poder a cada vez alcançado. Assim, o poder está constantemente a caminho 'de' si mesmo; não apenas a caminho do próximo estágio de poder, mas do apoderamento de sua essência pura". ${ }^{18}$

Esta passagem contém de maneira sintética os elementos centrais da interpretação heideggeriana da expressão "vontade de poder". A passagem aparece logo em seguida à menção a um dos capítulos mais famosos de Assim falou Zaratustra: "Do superar a si mesmo". Nesse capítulo, Nietzsche trata pela primeira vez explicitamente da vontade de poder como o "modo de ser de todo vivente" ${ }^{19}$ e assevera ao mesmo tempo a articulação entre as noções de vontade de poder, mando e obediência. Diante dessa apresentação e dessa articulação, a interpretação heideggeriana procura a princípio mostrar em que medida mando e obediência são traços primordiais da própria dinâmica da vontade e não podem ser pensados a partir de uma mera relação intersubjetiva qualquer: "Comandar é assenhorear-se do dispor de possibilidades, dos caminhos, dos modos e meios da efetivação atuante. O que é comandado no comando é a realização dessa disposição". ${ }^{20} \mathrm{Na}$ vontade de poder, estabelece-se, para Heidegger, uma relação com possibilidades, caminhos, modos e meios de uma certa atuação. Essa atuação encontra-se, por sua vez, em uma conexão direta com a própria dinâmica da vontade de poder. A vontade de poder é tomada acima por uma expressão que surge a partir de uma determinada compreensão da própria essência da vontade. De acordo com essa compreensão, a vontade não se encontra de maneira alguma presente para além do movimento do devir em um âmbito

18 M.Heidegger, Nietzsche II, em Gesamtausgabe, op.cit., vol. 6.2, pp. 265-6. Comparar também Nietzsche I, parte III, "Der Wille zur Macht als Erkenntnis (A vontade de poder como conhecimento)", em Gesamtausgabe, op.cit., vol. 6.1.

19 F.Nietzsche, Assim falou Zaratustra, em Kritische Studienausgabe, op.cit., vol.4, p. 146-48.

20 M. Heidegger, Nietzsche II, em Gesamtausgabe, op.cit., vol. 6.2, p. 265. 
transcendente ou mesmo imanente qualquer. Ela não é nenhuma substância autônoma, que "seria diversa como coisa em si de cada um de seus fenômenos"21. Ao contrário, ela é algo que não se resolve senão em meio à constituição mesma dos fenômenos, que sempre se essencializa no interior do próprio campo de formação desses fenômenos. O poder também nasce aqui desse processo de constituição, na medida em que surge a cada vez do aparecimento de uma malha relacional nas diversas configurações específicas da realidade. Assim, o poder não pode ser a meta da vontade, porque simplesmente não há nenhuma vontade que poderia se mostrar originariamente como independente frente ao poder aspirado, e a vontade não pode se desdobrar sem o poder, porque toda e qualquer dinâmica da vontade implica imediatamente o surgimento de redes de poder. Vontade e poder copertencem-se muito mais de uma maneira necessária. No que a vontade desdobra a sua própria essência, ela alcança simultaneamente a esfera do poder. Esse processo nunca atinge, porém, um ponto final, de modo que a essência da vontade precisa constantemente querer para além de si. Tal como se acha formulado em um fragmento póstumo de Nietzsche, datado do início do ano de 1888:

A vontade de acumulação é específica para o fenômeno da vida, para a alimentação, a geração, a herança, para a sociedade, o estado, o hábito, a autoridade (...). Não se tem apenas constância da energia, mas economia maximal do gasto: de maneira que o querer-vir-a-ser-mais-forte é a partir de cada centro de força a única realidade - não autoconservação, mas apropriação, querer-vir-a-ser-senhor, querer-vir-a-ser-mais, querer-vir-a-ser-mais-forte. (...) Quando algo acontece de um modo e não de outro, não há aí nenhum 'princípio', nenhuma 'lei', nenhuma 'ordem'. Só há centros de força, cuja essência consiste em exercer poder sobre todos os outros centros de força. ${ }^{22}$

Mas o que significa propriamente nesse contexto a palavra poder? Em que medida a realização da essência da vontade se estende realmente de maneira incessante para o interior da esfera do poder? Heidegger nos dá uma primeira

21 SCHOPENHAUER, Arthur. O mundo como vontade e como representação, $1^{\circ}$ tomo/ Arthur Schopenhauer; tradução, apresentação, notas e índices de Jair Barboza. - São Paulo: Eitora UNESP, 2005. § 23.

22 F.Nietzsche, Obra póstuma, Início do ano de 1888, em Kritische Studienausgabe, op.cit., vol, 13, p. 261. 
resposta a essas perguntas na última parte do trecho acima citado: "O poder só se realiza como poder, na medida em que se torna senhor sobre o estágio de poder a cada vez alcançado. O poder só é e só permanece como poder, quando permanece elevação de poder e comanda o mais em meio ao poder".

O conceito de poder aqui em questão também emerge da essência da vontade compreendida de uma maneira nova. Tal como vimos, a vontade não subsiste autonomamente fora do processo de configuração do mundo fenomênico, mas perpassa muito mais originariamente a vida desse processo. Desse processo sempre tomam parte a cada vez uma série de elementos que não possuem a priori nenhuma determinação. Toda e qualquer concreção da vontade sempre contém sentimentos, pulsões, elementos materiais etc. que só conquistam uma tal determinação em meio a essa concreção mesma. A concreção da vontade é assim marcada primordialmente por uma certa multiplicidade a priori indeterminada de elementos, que não se encontram absolutamente dispersos e independentes dela em um âmbito contraposto qualquer ${ }^{23}$. Porque a vontade não é nenhuma faculdade subjetiva, como é o caso, por exemplo, em Kant, mas muito mais o modo de ser maximamente originário de todo acontecimento, ela não permanece oposta a essa multiplicidade. Ora, mas se as coisas se dão dessa forma, precisamos perguntar: o que tem lugar afinal em meio a cada concreção da vontade? Cada concreção da vontade traz consigo ao mesmo tempo para Nietzsche um princípio interpretativo ${ }^{24}$, que integra a respectiva multiplicidade em uma certa conformação e firma do mesmo modo uma determinação relacional para ela. Desse modo, ela também implica o fato de esse princípio exercer poder sobre uma tal multiplicidade, o que faz com que ele se torne um princípio de poder. Com isso, a vontade essencializa-se efetivamente no âmbito essencial do poder, porque ela se exterioriza constantemente no interior da conformação de malhas de poder a partir de um princípio interpretativo pertencente a cada dinâmica da vontade. Se isso procede, então a significação do conceito de poder segue como que por si mesma. Nietzsche não compreende por um tal conceito nada além da unidade proveniente do processo de configuração da vida, cuja realidade efetiva não é outra senão a realidade de uma conformação de poder. Vontade de poder é nesse contexto uma expressão que dá voz ao movimento sempiterno desse processo. Ela nasce incessantemente da superação da inde-

23 Em relação ao caráter complexo de toda vontade, cf. F.Nietzsche, Para além do bem e do mal, § 16, em Kritische Studienausgabe, op.cit., vol. 5. Cf. também W. Müller-Lauter, Nietzsche Interpretationen III: Nietzsche und Heidegger, op.cit.

24 No que diz respeito ao caráter interpretativo de todo acontecimento, cf. antes de tudo G. Abel, Nietzsche Die Dynamik der Willen zur Macht und die ewige Wiederkehr, Berlin, Walter de Gruyter, 1984. 
terminação originária do todo, produz uma conformação de poder a partir do próprio jogo de forças vigente entre os elementos desse todo, abandona simultaneamente cada conformação alcançada e sempre se lança uma vez mais para a produção das conformações seguintes ${ }^{25}$. Essa compreensão da vontade de poder tem, então, uma conseqüência imediata para o problema do ser.

Heidegger interpreta a vontade de poder como o princípio construtivo de todas as possíveis configurações da realidade. Tudo o que é, tudo o que pode ser, tudo o que vem-a-ser, tudo o que pode vir-a-ser, em suma, todo ente é aqui pensado como vontade de poder. No interior do pensamento nietzschiano da vontade de poder, contudo, não reina de maneira alguma uma indistinção total. O que temos não é apenas uma incessante supressão de cada configuração da vontade de poder e a abertura ininterrupta para sempre novas configurações. Ao contrário, o próprio movimento de auto-superação da vontade carece da fixação daquilo mesmo que a cada vez é superado. "Para que a vontade possa ultrapassar a cada vez na superpotencialização de si mesma o seu respectivo estágio, esse estágio precisa ser anteriormente alcançado, assegurado e fixado. $\mathrm{O}$ asseguramento é a condição necessária da super-elevação do poder." ${ }^{26} \mathrm{O}$ ser de cada uma das configurações da vontade é em outras palavras indispensável para a própria vitalidade da vontade de poder, uma vez que a superação de si mesma por parte da vontade depende sempre de uma fixação daquilo mesmo que a vontade precisa superar. Com isso, nós chegamos a um ponto crucial na interpretação heideggeriana da vontade de poder.

A vontade de poder possui a sua essência na incessante superação de si mesma e no aquiescimento máximo à soberania inconteste do devir: ela sempre perpassa a multiplicidade indeterminada originariamente em jogo em cada configuração da totalidade, se abate radicalmente sobre essa multiplicidade, promove de maneira imanente o aparecimento de uma determinada configuração dessa totalidade, expõe a configuração alcançada a um novo processo configurador e sempre supera, assim, a si mesma no interior do movimento incessante do devir. Na medida em que leva a termo uma tal dinâmica, porém, a vontade de poder se mostra ao mesmo tempo como a única lei própria às configurações em geral. Bem, justo e verdadeiro passa a ser agora apenas o que corresponde à intensidade do movimento da vontade de poder. Tudo é medido segundo o valor da vontade de poder e a vontade de poder mesma se transforma, com isso,

25 Cf. O.Pöggeler, Neue Wege mit Heidegger, Freiburg - München, Alber, 1992, em particular p. 17.

26 M.Heidegger, A sentença nietzschiana “Deus está morto”, em Caminhos da Floresta, Gesamtausgabe, op.cit., vol. 5 , p. 237. 
em novo princípio do valor. Desse modo, Heidegger prossegue e nos diz logo em seguida à passagem supracitada:

A vontade precisa inserir o olhar em um campo de visão e abrir inicialmente esse campo, para que se mostrem pela primeira vez possibilidades que apontam o caminho de uma elevação do poder. A vontade precisa, assim, posicionar uma condição do querer-para-além-de-si. A vontade de poder precisa sobretudo posicionar as condições de conservação e elevação do poder. É constitutivo da vontade o posicionamento dessas condições em si copertinentes. ${ }^{27}$

No momento em que a vontade de poder assume um tal papel, a totalidade do ente passa a se mostrar como mera condição da dinâmica de elevação e conservação da vontade. No interior desse contexto, então, dá-se uma inversão radical da hierarquia própria à tradição metafísica. Uma inversão que não inverte, porém, a situação da questão acerca do ser, mas que consuma antes a essência niilista do pensamento metafísico. Para a tradição metafísica, a pergunta sobre o ser confunde-se com a pergunta sobre o ser do ente na totalidade. "A metafísica parte do ente e segue em direção ao ente. Ela não parte do ser e da dignidade de questão de sua manifestabilidade. ${ }^{" 28}$ Com isso, o ser ele mesmo permanece não questionado em sua verdade e a metafísica enreda-se, então, desde o princípio naquilo que Heidegger chama esquecimento do ser. Ao estabelecer o ser como presença constante, a metafísica desconsidera a diferença ontológica e trabalha incessantemente a partir do pressuposto do ser como um ente entre outros. A consumação da metafísica no interior do pensamento nietzschiano da vontade de poder não altera essa situação, mas a radicaliza ainda mais. Na medida em que a vontade de poder precisa assegurar as suas configurações a cada vez alcançadas, a fim de poder exercer o seu movimento de auto-superação, ela precisa encerrar uma certa dimensão de ser entendido como presença. Medido a partir da vontade de poder, o ser é um valor necessário. No entanto, ele é um valor de segunda grandeza em relação ao devir e à supressão incessante da presença a cada vez alcançada. O próprio ser que funcionava inicialmente como o ente supremo transforma-se, assim, em um valor secundário, em uma

27 Ibid., p. 237

28 M.Heidegger, Introdução à Metafísica, Gesamtausgabe, op.cit., vol. 40, p.139. 
mera condição de conservação/ elevação da dinâmica da vontade de poder. No momento em que isso se dá, rompe-se radicalmente a ligação originária entre o ser-aí humano e o ser.

Se o ser do ente recebe a marca de um valor e se a sua essência é, com isso, vencida, então no interior dessa metafísica, e isso significa sempre no interior da verdade do ente enquanto tal durante essa época, dissolve-se todo caminho para a experiência do próprio ser. ${ }^{29}$

Desse modo, Nietzsche coloca a metafísica de cabeça para baixo, mas não reinstaura o problema da verdade em um outro horizonte. Esse estado de coisas radicaliza-se ainda mais no interior da interpretação heideggeriana do eterno retorno do mesmo. Isso fica claro em um outro trecho do primeiro volume de sua preleção sobre Nietzsche:

A cunhagem, isto é, a conversão daquilo que vem a ser em ente, é a mais elevada vontade de poder. Nessa conversão, a vontade de poder alcança o mais puramente possível a validade em sua essência. O que é essa conversão na qual aquilo que vem a ser se torna ente? É a configuração daquilo que vem a ser em suas possibilidades extremas, nas possibilidades em que ele se esclarece e ganha subsistência em suas medidas e âmbitos. Essa conversão é o criar. Como criar para além de si, o criar é em sua dimensão mais intrínseca o seguinte: encontrar-se no instante da decisão, um instante no qual o que se deu até aqui e o que nos foi concomitantemente transmitido são elevados até o interior da tarefa pré-projetada e assim conservados. Essa instantaneidade do criar é a essência da eternidade real, atuante, que conquista a sua incisividade e amplitude extremas como o instante da eternidade do retorno do mesmo. A conversão daquilo que vem a ser em ente - a vontade de poder em sua figura suprema - é em essência a mais profunda instantaneidade: eterno retorno do mesmo. ${ }^{30}$

29 M.Heidegger, $A$ sentença nietzschiana "Deus está morto", em Caminhos da Floresta, Gesamtausgabe, op.cit., vol. 5, p. 258.

30 M. Heidegger, Nietzsche I, em Gesamtausgabe, op.cit., p. 466. 
Esta passagem é paradigmática para esclarecer a interpretação heideggeriana da vontade de poder em sua conexão com o pensamento do eterno retorno do mesmo. Ela fala desde o princípio sobre uma certa "conversão daquilo que vem a ser em ente". Essa conversão descreve a própria dinâmica do devir em sua independência absoluta frente a todo ser. Aquilo que vem a ser e, por conseguinte, o próprio devir tornam-se pela primeira vez ente, no momento em que não há mais nenhum ser autônomo e todo ente se conforma no interior do devir. Se o âmbito ontológico é aniquilado e tudo provém do devir, a vontade de poder alcança imediatamente a sua possibilidade mais elevada. Mas por que afinal? Para Nietzsche, a vontade de poder é uma expressão que se mostra como o único princípio de toda configuração vital. No entanto, ela não desempenha de maneira alguma esse papel porque constitui a substância originária da totalidade ou contém a ideia de uma constituição monadológica do mundo. Ela é muito mais um tal princípio, porque impera completamente sobre o processo mesmo de uma tal configuração. Toda conformação de domínio surge a partir da vontade de poder e é no interior dessa vontade que uma determinada perspectiva exerce poder sobre uma multiplicidade a cada vez em jogo, deixando surgir na vida uma determinada figura de poder. Para que a vontade de poder continue sempre mantendo esse seu caráter, porém, ela não pode se cristalizar em uma única configuração e precisa, por isso mesmo, querer constantemente para além de si. Nesse sentido, a noção de vontade de poder implica a presença do devir em sua possibilidade mais extrema. Justamente essa possibilidade mais extrema tem lugar no pensamento do eterno retorno do mesmo. Heidegger nos diz acima: "O que é essa conversão, na qual o que devém se torna ente? É a configuração do deveniente em suas possibilidades extremas, nas possibilidades em que ele se esclarece e ganha subsistência como em suas medidas e âmbitos."

O devir compreendido em seu sentido próprio não consiste pura e simplesmente em uma transformação incessante do mundo. Em última instância, não pode existir nenhum discurso real acerca de uma tal transformação radical, uma vez que ela aniquila todo solo de constituição dos discursos em geral ${ }^{31}$. Onde quer que tudo experimente uma transformação imediata em todas as suas dimensões, a vida não encontra nenhum lugar adequado para a configuração de uma de suas conformações. Exatamente por isso, é preciso que o devir conquiste algum tipo de subsistência, sem poder ao mesmo tempo cristalizar-se por meio daí. Uma tal subsistência, por sua vez, só pode ser alcançada se cada

$31 \mathrm{Cf}$. quanto a isso Aristóteles, Metafísica IV. 
conformação vital detiver um horizonte apropriado e puder se mostrar no interior desse horizonte. Em articulação com Nietzsche, Heidegger denomina esse horizonte o "instante do criar": "Como criar para além de si, o criar é em sua dimensão mais intrínseca o seguinte: encontrar-se no instante da decisão, no instante no qual o que se deu até aqui e o que nos foi concomitantemente transmitido são elevados em meio à tarefa pré-projetada e assim conservados." De acordo com essa passagem, portanto, o criar não implica conservação do configurar já alcançado, mas possibilita pela primeira vez efetivamente uma tal conservação por meio da elevação em direção a sempre novas possibilidades. O criar atua para além de si e supera, assim, constantemente o criado. Todavia, ele sempre assume uma vez mais nesse movimento o resultado de sua atividade. A assunção não acontece por meio da mera repetição de um tal resultado, mas muito mais por meio de sua apropriação no processo mesmo de configuração. E como esse processo aponta para a dinâmica da vontade de poder, ainda podemos acrescentar uma última coisa. Quanto maior é o obstáculo de cada conformação vital, tanto maior é o poder da vontade nela vigente. Assim, a apropriação suprema acontece em meio ao pensamento do eterno retorno do mesmo, na medida em que esse pensamento apresenta a eternidade como horizonte de toda conformação vital. A vontade de poder precisa superar aqui o obstáculo mais extremo, porque tem de superar eternamente cada conformação em jogo. Por meio do eterno retorno do mesmo surgem, em outras palavras, as possibilidades extremas da vontade de poder que descobre, então, a sua mais profunda subsistência no interior do devir. Na medida em que Nietzsche articula a ideia de um eterno movimento circular da totalidade com a sua concepção do instante, ele absolutiza, segundo a interpretação heideggeriana, a dinâmica da vontade de poder. Tudo deve eternamente retornar, a fim de experimentar sempre uma vez mais a realidade da vontade de poder no instante. Se isso está claro, então podemos agora responder à pergunta acerca das razões que levam Heidegger a tomar a filosofia nietzschiana pelo derradeiro enredamento no niilismo, assim como podemos conquistar uma primeira formulação do conceito heideggeriano de niilismo.

De acordo com a interpretação heideggeriana, a filosofia de Nietzsche apresenta o derradeiro enredamento no niilismo, porque leva a termo o acabamento de uma história na qual o ser mesmo nunca se acha em questão. "O ser mesmo permanece essencial e necessariamente impensado na metafísica. A metafísica é a história na qual não se tem nada em comum com o ser mesmo. A metafísi- 
ca é o próprio niilismo." 32 A filosofia de Nietzsche corporifica a consumação da essência da metafísica, o acabamento do fato de o ser nunca estar em questão no interior do pensamento metafísico. No entanto, ela só desempenha um tal papel, uma vez que o ser mesmo torna-se aí nada e o ente alcança um domínio absoluto:

Mas se o ser mesmo se retrai para o interior de seu abrigo mais distante e recôndito, o ente como tal ganha a totalidade de seu domínio e é liberado para se tornar a medida exclusiva para o 'ser'. O ente como tal aparece como vontade de poder na qual o ser como vontade leva a sua subjetividade ao acabamento. Sua metafísica deixa o ser de fora tão decididamente que ele permanece encoberto em meio ao pensamento valorativo e esse pensamento mesmo quase não se deixa mais saber e vigorar como metafísica. No que a metafísica impele para o turbilhão de sua exclusão, esse turbilhão se consuma e se transforma, incognoscível como tal, na verdade do ente em detrimento da verdade do ser. Contudo, em sintonia com a cegueira vigente da metafísica em relação a si mesma, esse enredamento aparece como a liberação em relação a toda metafísica. ${ }^{33}$

Em articulação com a determinação do pensamento de Nietzsche, podemos então trazer à tona a própria concepção heideggeriana do niilismo.

O conceito heideggeriano de niilismo não significa nada além de "abandono do ser". Tal como foi mostrado detalhadamente nas últimas páginas, esse abandono do ser sempre acontece a princípio por meio da redução da totalidade do ente à dinâmica do vir-a-ser constante da vontade de poder: por meio de uma tentativa de superar a história da metafísica que acaba por levar simplesmente a termo a própria essência dessa história. O niilismo mostra-se neste caso como o resultado de uma figura de pensamento que abre o domínio absoluto do ente sobre o ser. Na medida em que essa figura de pensamento não é apenas uma possibilidade do pensar filosófico, mas se confunde muito mais com o modo de abertura da totalidade do ente na contemporaneidade, ela conquista ao mesmo

32 M.Heidegger, Metaphysik und Nihilismus, em Gesamtausgabe, op.cit., vol. 67, p. 216.

33 Ibid. p. 244 
tempo uma outra amplitude. Niilismo passa a ser a nossa conjuntura fundamental. Em Heidegger, essa conjuntura se encontra em conexão essencial com o problema da técnica.

\section{Niilismo e técnica}

Heidegger não entende em geral o fenômeno da técnica a partir de uma apresentação instrumental ou mesmo antropológica de seu modo de ser. Já no começo de seu texto A pergunta pela técnica, ele diz de maneira explícita:

A representação corrente da técnica, segundo a qual ela é um meio e um fazer humano, pode (...) ser designada a determinação instrumental e antropológica da técnica. Quem poderia negar que ela é correta? Ela se orienta notoriamente pelo que se tem diante dos olhos quando se fala em técnica. A determinação instrumental da técnica é mesmo tão extensamente correta que ela também é pertinente para a técnica moderna, da qual se afirma de mais a mais com uma certa razão que ela é algo inteiramente diverso e, por isso, novo em relação à técnica artesanal mais antiga. (...) $\mathrm{O}$ correto sempre constata a cada vez algo exato no que se dá e está diante de nós. Para ser correta, porém, a constatação do certo e do exato não precisa de maneira alguma desentranhar o que se dá e apresenta em sua essência. Somente onde se dá um tal desentranhamento acontece apropriativamente o verdadeiro. Por isso, o meramente correto ainda não é o verdadeiro. Somente este último nos traz para o interior de uma relação livre com o que a partir de sua essência nos concerne. A determinação instrumental correta da técnica ainda não nos mostra conseqüentemente a sua essência. Para que alcancemos uma tal essência ou para que ao menos nos aproximemos dela, precisamos buscar através do correto o verdadeiro. ${ }^{34}$

Essa passagem apresenta-se à primeira vista como uma crítica à determinação instrumental da técnica. No entanto, não temos aí uma mera recusa a essa determinação. Ao contrário, também temos essencialmente uma indicação

34 M. Heidegger, A pergunta sobre a técnica, em Ensaios e Conferências, em Gesamtausgabe, op.cit., vol. 7, pp. 8-9. 
direta do caminho necessário de investigação de sua essência. De acordo com a interpretação heideggeriana, a determinação instrumental é sem dúvida alguma correta, ou seja, ela certamente corresponde de maneira plena ao objeto que está presente na aparição. Em outras palavras, se fixarmos esse objeto e o analisarmos em suas propriedades específicas, é evidentemente correto formular o enunciado proposicional que afirma o fato de a técnica ser um meio para a realização de fins. Todavia, a sua correção mesma repousa sobre um critério mais originário. Heidegger repete aqui um estado de coisas que ele apresenta mais detalhadamente em seu importante ensaio Da essência da verdade:

De onde o enunciado representacional retira a indicação para se orientar pelo objeto e para ser consoante com a correção? Por que essa consonância determina a essência da verdade? Como é que pode afinal acontecer algo do gênero da dotação de medida de uma correção e da inserção em uma consonância? Apenas de um modo tal que esse estabelecimento de uma medida já tenha sido liberado em meio a um aberto para algo revelado vigente a partir desse aberto, algo que vincula todo e qualquer representar. ${ }^{35}$

A correção da determinação instrumental da técnica cria, em outras palavras, como que por si mesma o espaço para que investiguemos o "revelado vigente" que possibilita o surgimento da técnica. O que interessa no fundo a Heidegger não depende absolutamente da técnica mesma em sua realidade objetiva, mas muito mais da técnica como modo possível da abertura do ser. Em sintonia com isso, precisamos abdicar de uma investigação direta da técnica, a fim de podermos considerar aquele descerramento determinado do ente na totalidade que pertence à essência da técnica. Dito sucintamente, precisamos nos abrir para o destino do ser no interior do mundo da técnica. No que concerne a essa tarefa, encontramos uma formulação decisiva no ensaio heideggeriano sobre a técnica:

Aquele desencobrimento dominante na técnica moderna não se desdobra... em uma pro-dução no sentido da poi/ hsij. O desencobrimento vigente na técnica moderna é uma provocação que apresenta à natureza a exigência de

35 M. Heidegger, Da essência da verdade, em Wegmarken, em Gesamtausgabe, op.cit., vol. 9, pp. $185-6$. 
fornecer energia, capaz de, como tal, ser beneficiada e armazenada. Isso também não vale, porém, para o antigo moinho de vento? Não! Suas alas giram, sem dúvida, ao vento e são diretamente confiadas a seu sopro. Mas o moinho de vento não extrai energia das correntes de ar para armazená-las. ${ }^{36}$

A passagem acima traz consigo um conceito decisivo para a compreensão do modo de abertura do ente na totalidade que tem lugar em meio ao universo da técnica. De início, não podemos perder de vista o fato de a palavra "provocação" dar voz ao desvelamento vigente no mundo da técnica contemporânea. Portanto, ela designa aqui o modo a partir do qual o todo do ente é compreendido no interior da técnica. Essa compreensão não permanece indiferente em relação ao ente, mas faz com que ele apareça desde o princípio de acordo com um determinado caráter ontológico. A técnica apresenta, como nos diz Heidegger, uma exigência fundamental à natureza. Essa exigência causa, então, uma transformação ontológica na natureza como um todo. Por meio daí, ela não vem mais à tona como algo por-si-subsistente que cresce-e-vige-a-partir-de-si-mesmo ${ }^{37}$, mas passa a experimentar uma certa modificação. Em sintonia com a exigência técnica, a natureza só conquista aqui o seu lugar próprio, na medida em que está em condições de "fornecer energia capaz de, como tal, ser beneficiada e armazenada". Assim, a técnica contemporânea coloca a natureza em uma conjuntura, a partir da qual ela passa a desempenhar o papel de fornecedora de energia. No entanto, para que a natureza esteja em condições de desempenhar um tal papel, ela precisa necessariamente conter em si uma quantidade de energia que possa fazer frente a uma tal provocação. O posicionamento da técnica deve acontecer por meio do fato de que "a energia escondida na natureza é revelada, o descerrado é transformado, o transformado armazenado, o armazenado uma vez mais distribuído e o distribuído novamente processado" ${ }^{\text {"38 }}$. Mas como é que precisamos entender a natureza, para que ela se mostre como fornecedora de energia e esteja sempre pronta a preencher o posicionamento provocador da técnica? Heidegger responde essa pergunta por meio do conceito de fundo de reserva:

36 M. Heidegger, A pergunta sobre a técnica, op.cit., p.15.

37 É assim que a palavra physis é interpretada na preleção de Heidegger de 1929/30, Os conceitos fundamentais da metafisica (mundo - finitude - solidão). M. Heidegger, Die Grundbegriffe der Metaphysik. Welt - Endlichkeit - Einsamkeit, em Gesamtausgabe, op.cit., Bände 29-30, p. 54.

38 M. Heidegger, A pergunta sobre a técnica, op.cit., p.17 
Por toda parte se coloca a requisição (em relação ao que vem a termo por meio da colocação provocadora) para estar a postos, e, assim estar, a fim de ser ele mesmo requisitável para a colocação de uma outra requisição. O que é assim requisitado tem seu próprio esteio. Nós o denominamos fundo de reserva. A expressão diz aqui mais e também algo mais essencial do que apenas 'provisão'. A expressão 'fundo de reserva' ganha agora o estatuto de uma categoria. Ela não caracteriza nada menos do que a maneira como tudo o que é afetado pelo desencobrimento provocador se essencializa ${ }^{39}$

A natureza precisa ser tomada por um fundo de reserva, para que o homem possa empreender a provocação técnica. Com isso, essa provocação pressupõe o seguinte: a natureza já precisa estar de antemão de tal modo simplesmente dada, que a técnica possa se abater sobre ela, assegurar seu poder por meio desse movimento e nunca alcançar uma estação final. Como já foi dito, a técnica faz em primeiro lugar uma exigência à natureza de que ela forneça energia. No entanto, no que a natureza cumpre um tal papel, ela não permanece absolutamente vazia, nem é tampouco colocada de lado. Não acontece aqui de maneira alguma de a natureza já utilizada precisar ser substituída após a provocação. Muito pelo contrário, o fornecimento de energia implica ao mesmo tempo a recuperação incessante da natureza como fornecedora de energia. Segundo a interpretação heideggeriana da técnica, a essência da técnica corresponde plenamente à ideia de reciclagem que se tornou hoje tão corrente. Essa ideia não tem em comum por sua vez apenas com uma parte da natureza, mas se estende estruturalmente até o ente na totalidade. A presença de todo ente provém nesse contexto do desencobrimento provocador inerente ao mundo da técnica. Um tal desencobrimento repousa sobre a compreensão da natureza como fundo de reserva. Por isso, o ser de todos os entes aparece aqui como fundo de reserva, como matéria indeterminada e irrelevante em suas possíveis determinações, como energia resguardada que está sempre uma vez mais disponível para a voracidade da dinâmica da vontade técnica. Mas se o ser de todos os entes é aberto como fundo de reserva e tudo está assim inserido em um processo de articulação provocadora, o que acontece aí imediatamente com o ser do ser-aí? Heidegger expressa-se sobre isso em uma outra passagem do escrito sobre a essência da técnica:

39 Ibid. 
(...) se o destino impera sob o modo da composição, então ele se torna o mais extremo perigo. Esse perigo se nos anuncia segundo dois aspectos. Logo que o desvelado não toca mais o homem como objeto, mas exclusivamente como fundo de reserva e o homem se reduz apenas a requisitar o fundo de reserva em meio à ausência de objetos, - então o homem se vê diante da última beira do precipício, lá onde ele mesmo não é mais tomado senão como fundo de reserva. Entretanto, o homem assim ameaçado se alardeia na figura de senhor da terra. Com isso, cresce a aparência de que tudo o que vem ao seu encontro só subsiste, na medida em que é um artefato do homem. Essa aparência faz prosperar uma derradeira ilusão, segundo a qual, em toda parte, o homem só se encontra consigo mesmo. Heisenberg mostrou com toda a razão que é assim mesmo que o real deve apresentar-se ao homem atual. Contudo, o homem hoje não vem mais em lugar algum ao encontro de si mesmo, isto é, ao encontro de sua essência. O homem encontra-se tão decididamente no cortejo da provocação da composição que ele já não a toma como um apelo, que ele mesmo nem se sente interpelado por essa provocação em meio à composição. Com isso, ele não escuta nenhum aceno para em que medida ele ek-siste a partir de sua essência no âmbito de um apelo e por isso nunca pode vir ao encontro apenas de si mesmo. ${ }^{40}$

Heidegger fala-nos nessa passagem desde o princípio sobre um certo perigo que se acha em ligação com o destino do ser-aí no contexto da composição. $\mathrm{O}$ que se tem em vista aí por "composição" aponta imediatamente para a estrutura que emerge da provocação originária da natureza levada a termo pela técnica, uma provocação que se realiza incessantemente em sintonia com uma vontade que sempre posiciona o todo do ente de tal modo que esse posicionamento mesmo não surge senão de um co-posicionamento ontologicamente anterior do próprio modo de posicionar. "Composição" significa no presente contexto absolutização da noção de ser como posição e autonomização da vontade técnica que em tudo o que posiciona já sempre posicionou a si mesma. Para

40Ibid.,p.28 
uma tal posição, é decisiva a relação da composição com a determinação dos entes como fundo de reserva. Como está formulado no ensaio $A$ pergunta pela técnica: composição é "aquela reivindicação provocadora que reúne o homem e o projeta ${ }^{41}$ para a colocação de uma requisição ao que se descobre como fundo de reserva" ${ }^{42}$. Portanto, o destino do ser-aí na era da técnica é entregar a si mesmo à essência da composição. No que algo acontece desse modo, porém, o ser-aí conquista ao mesmo tempo um novo modo de se comportar em relação ao ente na totalidade. A partir desse momento, ele não se determina mais como sujeito, que representa o ente e o objetiva. No interior da composição enquanto o "modo do desencobrimento que impera na técnica moderna (PST, EC, GA 7, 21)", os entes perdem completamente a sua objetividade e só aparecem como fundo de reserva. Por isso, o ser-aí não pode mais conhecer o ente como objeto, mas precisa incessantemente requisitá-lo como fundo de reserva. Ele torna-se, em outras palavras, aquele que "requisita o fundo de reserva". Na medida em que o homem desempenha um tal papel, ele mesmo acaba por se tornar mero fundo de reserva, porque é absolutamente absorvido no modo de colocação da requisição técnica e na armação enquanto a subjetividade própria a essa requisição ${ }^{43}$. O homem acredita inicialmente no seu poder sobre a totalidade do aparato tecnológico e vê, com isso, a técnica como um mero instrumento para a resolução de suas finalidades de domínio da natureza em geral. A própria constituição da requisição técnica, contudo, inviabiliza uma tal ilusão. Não é nunca o homem que apresenta efetivamente a requisição técnica, pois a própria requisição obedece a uma transformação da totalidade anterior a todo e qualquer comportamento possível do ser-aí humano, uma transformação que nasce em sintonia com a abertura do ente na totalidade característica do mundo da técnica. Em função dessa transformação e dessa abertura, o homem não pode senão se colocar na posição aberta pela composição, ou seja, a posição daquele que requisita. A questão é que o surgimento dessa posição já sempre exige a presença de uma subjetividade autônoma que seja responsável por essa função, uma subjetividade que reúna em si o modo como a requisição a cada vez se dá. No presente contexto, a composição mostra-se exatamente como uma tal subjetividade: a composição é "a requisição provocadora que reúne o homem em vista da solicitação do fundo de reserva." ${ }^{44}$ Nesse sentido, o homem nunca

41 Há aqui uma evidente conexão com o conceito de logos. A técnica é o logos do homem moderno no sentido de que ela unifica e viabiliza o projeto existencial desse homem

42 Ibid.

43 Ibid, p. 21

44 Quanto ao conceito heideggeriano de composição (Gestell), cf. o excelente ensaio de 
encontra a si próprio no mundo da técnica, porque ele passa a se realizar incessantemente a partir de uma absorção inicial na subjetividade incondicionada da armação. Se tivermos clareza quanto a esse ponto, não é difícil mostrar como essa absorção corresponde completamente à apresentação feita anteriormente da interpretação heideggeriana da expressão vontade de poder em Nietzsche.

Se nos lembrarmos rapidamente da interpretação heideggeriana da vontade de poder, não será difícil determinar em que medida ela se encontra em conexão essencial com a afirmação da absorção absoluta do homem na composição em meio à era da técnica. O ponto central da interpretação que Heidegger faz de Nietzsche repousa justamente sobre a asserção da dissolução de toda transcendência e do domínio irrestrito daí emergente da dinâmica da vontade de poder. De acordo com o pensamento de Nietzsche, a supressão do modo metafísico de compreensão da realidade traz consigo o domínio de uma vontade que exerce incessantemente o seu poder sobre a totalidade do ente e só mantém esse poder, na medida em que constantemente se projeta para além de si mesma. O princípio do poder não provém, por sua vez, de nenhum âmbito extrínseco, mas só se dá muito mais a partir da própria essência da vontade. No que concerne à expressão vontade de poder, ela provoca o aparecimento imediato de uma transposição do ente para uma conjuntura, na qual ele passa a se achar constantemente sob o poder do processo de realização da vontade. A vontade de poder requisita aqui por assim dizer o ente na totalidade de um tal modo, que esse aparece como fundo de reserva para o desenvolvimento de sua própria dinâmica de poder. Exatamente como mencionamos anteriormente em relação às noções de mando e obediência, essas noções não implicam senão a ideia de uma disponibilidade sobre... Essa ideia coloca o ente na totalidade à disposição da vontade de poder que vige em meio a uma tal disposição. Vontade de poder é, assim, a configuração essencial de uma vontade que, antes mesmo de querer alguma coisa determinada, precisa querer a si mesma como princípio de constituição de tudo o que quer. Justamente isso, porém, ganha voz no interior do universo da técnica: a técnica realiza o domínio irrestrito da vontade de poder como vontade de vontade ${ }^{45}$. Heidegger mesmo nos diz isso expressamente em uma pequena passagem de seu ensaio Superação da metafísica:

I.B.Duarte, "La tesis de Heidegger sobre la técnica", em Anales del Seminario de Historia de la Filosofia, Madrid, 10, 1993, pp. 119-154.

45 Cf. quanto a esse ponto M.Zimmerman, Heidegger's confrontation with modern technology, politics and art, Indiana, Indiana University Press, 1999; e G. Seubold, Heideggers Analyse der neuzeitlichen Technik, Freiburg - Munique, Alber, 1986. 
A época da metafísica levada ao acabamento encontra-se diante de seu começo. A vontade de vontade impõe a si mesma como as suas formas fundamentais de aparição o cálculo e a ordenação de tudo. Todavia, isso só se dá para o asseguramento passível de ser levado adiante. A forma fundamental de aparecimento, segundo a qual a vontade de vontade erige e contabiliza a si mesma no não-histórico do mundo da metafísica levada à consumação, pode ser chamada de maneira concisa 'a técnica'. Esse termo abarca aí todas as regiões do ente que aprontam a cada vez o todo do ente: a natureza objetivada, a cultura empreendida, a política feita e o ideal estabelecido como uma superestrutura. (...) A noção de 'a técnica' é aqui compreendida tão essencialmente, que ela equivale em sua significação à expressão: a metafísica levada ao acabamento. (...) O termo viabiliza ao mesmo tempo o fato de o caráter planetário do acabamento da metafísica e de seu domínio poderem ser pensados sem qualquer referência a variações historiológicas comprováveis de povos e continentes. (...) A metafísica de Nietzsche traz à tona em meio à vontade de poder o penúltimo estágio do desdobramento da vontade da entidade do ente como vontade de vontade. ${ }^{46}$

\section{Do homem entediado ou o tédio da era técnica}

Heidegger não concebe a técnica moderna a partir de um ponto de vista instrumental ou antropológico. Ao contrário, ele procura pensar desde o princípio o acontecimento da técnica a partir muito mais do modo de constituição da abertura que esse acontecimento possibilita. Dito de maneira ainda mais expressa, ele procura incessantemente escapar de todo enredamento em uma compreensão ôntica da técnica, para alcançar por meio daí um caminho de consideração da medida ontológica que vem à tona juntamente com a decisão pela técnica. Assim, a técnica não surge como mais um fenômeno entre outros do complexo mundo cultural contemporâneo, mas antes como a dimensão que concretiza em

46 M.Heidegger, Superação da metafisica, em Ensaios e conferências, em Gesamtausgabe, op.cit., vol. 7, pp. 78-9. 
si o modo fundamental de determinação do espaço existencial dos seres-aí na contemporaneidade. Nas palavras do ensaio A pergunta pela técnica:

Onde e como acontece o desencobrimento, se ele não é um mero construto do homem? Não precisamos ir buscar muito longe. O necessário é apenas apreender, sem nenhuma tomada de posição prévia, aquilo que já sempre fez uma requisição ao homem; e de maneira tão decidida que ele só pode ser homem como aquele que é assim interpelado. Onde quer que o homem abra seus olhos e seus ouvidos, onde quer que ele desobstrua seu coração, se entregue livremente ao meditar e ao aspirar, ao forjar e ao obrar, ao pedir e ao agradecer, ele já se encontra lançado no desvelado. Seu desvelamento já aconteceu apropriativamente, tão frequentemente quanto ele evocou o homem para os modos que lhe são apropriados do desencobrimento. Se o homem à sua maneira desencobre o presente, então ele apenas corresponde ao apelo do desvelamento, mesmo lá onde ele o contradiz. Portanto, se o homem se coloca investigativamente, meditativamente no encalço da natureza como uma região de seu representar, então ele já está sob o domínio da reivindicação de um modo do desencobrimento, que o provoca a se aproximar da natureza como um objeto da investigação, e isso até o ponto em que mesmo o objeto se dissipa na ausência de objeto. ${ }^{47}$

Por meio do modo de requisição empreendido em meio ao desvelamento surge, assim, um modo de constituição da abertura. No caso do mundo da técnica, esse desvelamento aponta justamente para uma compreensão do ente na totalidade, em meio à qual esse ente não se mostra senão como um fundo de reserva que se encontra sempre uma vez mais à disposição da provocação feita pela composição posicionante e coposiconada intrínseca a esse acontecimento mesmo. Uma vez que essa medida remete para o modo de compreensão do ente na totalidade vigente no mundo contemporâneo, ela acaba por se instituir como princípio de estruturação das possibilidades existenciais dos seres-aí no interior desse mundo. De início e

$47 \mathrm{Ibid}, \mathrm{p} .19$ 
na maioria das vezes, os seres-aí em geral se movimentam no mundo da técnica a partir de uma articulação essencial com a provocação que transforma o todo em fundo de reserva e com a subsunção de si mesmo ao aparato da composição. Essa articulação e subsunção dão voz ao domínio irrestrito da vontade de vontade.

Vontade de vontade é a expressão do princípio de realização da técnica moderna. Por ser armação provocadora do fundo de reserva, a essência da técnica já sempre aponta para a dinâmica de uma vontade que antes mesmo de querer o que quer que seja precisa querer a si mesma. No momento em que ela se instaura, temos uma transformação imediata do ente na totalidade em uma instância que pode fazer frente à sua própria requisição constitutiva. $\mathrm{O}$ que ela requisita é, por sua vez, que todas as coisas possam se mostrar como fundo disponível e inicialmente indeterminado, sobre o qual se abate então o seu princípio ordenador. Para fazer frente a essa requisição, o ente na totalidade precisa perder o seu caráter objetivo e passar a se constituir plenamente em meio à subsunção de si à dinâmica de um tal princípio. Não é mais possível pensar aqui em uma objetividade contraposta à subjetividade da vontade de vontade, uma vez que o processo de configuração mesmo do ente na totalidade é completamente absorvido por essa dinâmica. O que temos é o aparecimento de uma subjetividade incondicional e incondicionada que se estende cada vez mais intensamente para tudo o que se apresenta e pode se apresentar. Desse aparecimento vem à tona justamente a ligação entre provocação técnica, fundo de reserva e composição. Algumas são as conseqüências diretas dessa ligação: o ser-aí acaba aí por perder quase totalmente a possibilidade de experimentar o acontecimento do desvelamento e não se apropria por conseguinte de si mesmo como o ente aberto para um tal acontecimento; em meio a essa perda tem lugar uma absorção radical do ser-aí na medida do mundo técnico e uma transformação final de si próprio também em fundo de reserva; essa absorção e essa transformação acabam por provocar um acirramento da perda de si próprio e por colocar em risco a própria ligação essencial do ser-aí com a verdade do ser. Tal como aparece formulado no final do ensaio A pergunta pela técnica:

O essencializante da técnica ameaça o desencobrimento, o acossa com a possibilidade de que todo desencobrimento deságüe na requisição e tudo se apresente apenas no desvelamento do fundo de reserva. $\mathrm{O}$ agir humano nunca pode vir imediatamente ao encontro desse perigo. A capacidade humana nunca pode sozinha banir o perigo. No 
entanto, a meditação humana pode lembrar que tudo o que salva precisa ser de uma essência mais elevada, mas ao mesmo tempo aparentada com o que põe em risco. ${ }^{48}$

Mas em que medida esse risco acima descrito de o ser-aí se ver radicalmente imerso em um horizonte de abertura no qual tudo já sempre se mostra a partir da articulação essencialmente técnica entre requisição/provocação e fundo de reserva implica efetivamente um acirramento da perda de si próprio? Qual a relação entre perda de si próprio e tédio? Como precisamos entender em última análise a ligação entre tédio e técnica?

A afirmação heideggeriana de que a técnica traz consigo o risco de uma absolutização da dinâmica de constituição da totalidade como fundo de reserva produz uma transformação radical não apenas da natureza ou dos entes intramundanos em geral, mas também e principalmente do próprio destino do ser-aí. Exatamente como Heidegger explicita no contexto do conceito nietzschiano de além-do-homem:

A subjetividade da vontade de poder levada ao acabamento é a origem metafisica da necessidade essencial do 'além-do-homem' (...) A mesma conversão da subjetividade da razão incondicionada para a subjetividade incondicionada da vontade de poder transpõe agora, porém, ao mesmo tempo, a subjetividade no pleno poder ilimitado do desdobramento exclusivo de sua própria essência. Agora, a subjetividade como a vontade de poder em meio à legitimação da sobre-dominação só quer pura e simplesmente a si mesma como poder. Querer a si mesmo significa aqui: trazer-se para diante de si em meio ao acabamento da própria essência e dessa forma ser essa própria essência. A subjetividade levada ao acabamento precisa lançar a partir de sua mais profunda interioridade sua própria essência para além de si. Por si só, a subjetividade levada ao acabamento veda um fora de si mesma. Nada faz a requisição pelo ser sem se encontrar na esfera de poder da subjetividade levada ao acabamento. Mesmo o suprassensível e o âmbito de um Deus suprassensível desmoronaram. Agora é preciso que o homem, na medida em que somente ele se mostra como vontade representadora, instauradora de valores em meio ao ente como

48 Ibid., pp. 34-5. 
um tal na totalidade, ofereça à subjetividade levada ao acabamento os sítios de sua essência pura. Por isso, a vontade de poder como a subjetividade levada ao acabamento não pode colocar sua essência senão no sujeito em que o homem é, e, em verdade, aquele homem que está além do homem até aqui. Assim, colocado em seu extremo, a vontade de poder como a subjetividade levada ao acabamento é o sujeito mais elevado e único, isto é, o além-do-homem. Esse não vai além da essência do homem até aqui de maneira niilista, mas ao mesmo tempo como a conversão dessa essência sobre si mesma em sua dimensão incondicionada. A nova humanidade em meio ao ente que é na totalidade desprovido de metas e como tal vontade de poder, precisa, se ela quer a si mesma e quer segundo seu modo de ser uma meta, necessariamente querer o além-do-homem. (...) O além-do-homem vive, no que a nova humanidade quer o ser do ente como vontade de poder. ${ }^{49}$

Nós nos vimos diante da necessidade de citar essa longa passagem porque ela encerra em si sinteticamente os elementos centrais da concepção heideggeriana da técnica. Logo de início deparamo-nos com uma associação entre a "subjetividade da vontade de poder levada ao acabamento" e "a origem metafísica da necessidade essencial do além-do-homem". No que concerne ao primeiro termo dessa associação, ele nos fala do processo de transição de uma subjetividade que se assegura incessantemente de seu lugar como sede de toda representação por meio da conformação de si mesma como instauradora dos mais diversos objetos representados para uma subjetividade que simplesmente impõe o seu princípio de comando a uma multiplicidade de elementos e que dispõe radicalmente desses elementos em meio à sua dinâmica de auto-realização. A subjetividade incondicionada da vontade de poder não pressupõe mais absolutamente nenhuma dimensão de em si para os entes em geral, nem se movimenta inicialmente a partir da pressuposição de uma substancialidade subjetiva que controla extrinsecamente a dinâmica de configuração do mundo objetivo. Por um lado, não se tem mais aqui limites objetivos para as possibilidades de interpretação dos fenômenos, uma vez que a coisa em si se mostra finalmente como algo "tão equivocado quanto um sentido-em-si ou uma significação em

49 M.Heidegger, Nietzsche II, op.cit., pp. 302-4. Cf. quanto à interpretação heideggeriana do conceito de além-do-homem em Nietzsche, cf. W. Müller-Lauter, Nietzsche Interpretationen III: Nietzsche und Heidegger, op.cit. 
si" ${ }^{50}$. No entanto, por outro lado, tampouco se tem limites subjetivos para o estabelecimento dos modos mesmos de condução das interpretações, uma vez que um sujeito tomado como suporte ontológico da ação de pensar não é senão uma "conseqüência derivada da falsa observação interna que acredita em pensamento" "51. Tal como se acha formulado em um aforismo central de $A$ gaia ciência intitulado "Nossa nova infinitude":

Já estamos hoje ao menos distantes da imodéstia risível de decretar a partir de nosso canto que só se tem o direito de possuir perspectivas a partir desse canto. O mundo se nos tornou uma vez mais 'infinito', porquanto não podemos mais rejeitar a possibilidade de ele encerrar em si infinitas interpretações. ${ }^{52}$

A dinâmica da vontade de poder implica, assim, um alargamento tão descomunal dos limites de concretização de si mesma, que ela não merece senão a denominação de incondicional. Todavia, a incondicionalidade da vontade de poder não implica uma ruptura radical com a metafísica da subjetividade moderna. Ao contrário, ela continua perfazendo ainda um modelo de subjetividade, porque há ainda a manutenção de um traço característico do modo de estruturação da subjetividade moderna. Por mais que a dinâmica da vontade de poder não envolva mais a ideia de uma substancialidade subjetiva até certo sentido autônoma em relação às diversas perspectivas que transpassam os acontecimentos em geral, ela continua se assegurando de si mesma na medida em que leva a termo um determinado processo de conformação do mundo fenomênico. De acordo com uma série de formulações presentes na obra de Nietzsche, a vontade de poder não possui em si mesma nenhuma concretude específica e só se determina efetivamente a partir da capacidade de exercer poder sobre e de resistir ao poder de outras vontades de poder. Vontade de poder é uma expressão que implica necessariamente um embate originário entre princípios perspectivísticos de interpretação da totalidade e que encontra nesse embate o espaço de determinação de cada um desses princípios. Em meio ao embate surge um direcionamento volitivo a partir do qual nasce então um arranjo dos ele-

50 F.Nietzsche, Obra póstuma, em Kritische Studienausgabe, op.cit., vol. 12, 2(149).

51 F.Nietzsche, Obra póstuma, em Kritische Studienausgabe, op.cit., vol. 13, 11(113).

52 F.Nietzsche, Gaia ciência, em Kritische Studienausgabe, op.cit., vol. 3, §374.

EKSTASIS: revista de hermenêutica e fenomenologia 215 
mentos aí em jogo. Se a perspectiva intrínseca a uma vontade de poder é forte o suficiente para englobar as outras perspectivas concorrentes, ela tem uma maior quantidade de poder. Se ela não se mostra como detentora de uma tal força, ela tem uma menor quantidade de poder. Com isso, o que temos é o seguinte: cada vontade de poder acha-se em si mesma indeterminada. Essa indeterminação só é ultrapassada no interior de um embate contra outras vontades de poder, de tal modo que se revela aí a dimensão do poder inerente a um certo direcionamento da vontade. Por intermédio da dinâmica da vontade de poder em sua luta contra outras vontades de poder, a perspectiva estruturadora da malha de poder a cada vez alcançada é colocada em jogo. No entanto, a perspectiva só é colocada em jogo aqui, para que possamos efetivamente nos assegurar de sua incondicionalidade: para que tudo o que é possa estar à sua disposição e caia inteiramente sob o seu domínio. É certo que o embate originário entre as vontades de poder pode provocar o aparecimento de uma degradação de um certo princípio perspectivístico. Todavia, como essa degradação sempre tem lugar em meio ao embate acima descrito e sempre envolve também ao mesmo tempo o surgimento de um novo princípio perspectivístico, ela não se dá senão em nome da própria vontade de poder. Em tudo sobre o que se abate, a vontade de poder sempre acaba por experimentar a si mesma e o ente na totalidade vem à tona, por fim, como o mero espaço de realização de uma experiência incessante relativa ao próprio poder da vontade. Abertos estão todos os mares à sanha incondicionada da vontade de poder. Nas palavras de Heidegger na passagem acima citada:

Agora, a subjetividade como a vontade de poder em meio à legitimação da sobre-dominação só quer pura e simplesmente a si mesma como poder. Querer a si mesmo significa aqui: trazer-se para diante de si em meio ao acabamento da própria essência e dessa forma ser essa própria essência. A subjetividade levada ao acabamento precisa lançar a partir de sua mais profunda interioridade sua própria essência para além de si.

A subjetividade da vontade de poder se projeta constantemente para frente, mas nunca se depara senão consigo mesma em meio a um tal movimento. $\mathrm{Na}$ medida em que não pode interromper o processo do embate contra outras vontades de poder em momento algum, ela se realiza ininterruptamente em sintonia 
com a extensão de seu "poder sobre". Por mais que uma certa concreção da vontade de poder repentinamente definhe e inicie um processo de perecimento, esse processo mesmo só se faz em nome de uma nova concreção da vontade de poder oriunda do embate mesmo que produziu um tal definhamento.

"Por si só, a subjetividade levada ao acabamento veda um fora de si mesma. Nada faz a requisição pelo ser sem se encontrar na esfera de poder da subjetividade levada ao acabamento". Com essas palavras, Heidegger apenas ratifica o que vimos mostrando acima. Subjetividade levada ao acabamento é uma expressão que designa fundamentalmente a passagem da subjetividade pensada como sede de toda representação para a subjetividade incondicionada da vontade de poder. No que concerne a essa passagem, o que tivemos a oportunidade de perceber nos últimos parágrafos é que ela aponta para uma absolutização da dinâmica da vontade de poder ${ }^{53}$. De acordo com o pensamento nietzschiano, nunca temos nenhuma determinação ontológica dos entes em geral senão por meio do processo de estruturação do real a partir do embate entre vontades de poder. Com isso, não podemos senão concluir com Heidegger que a subjetividade levada ao acabamento alija toda e qualquer possibilidade do surgimento de um ser para além dela mesma, uma vez que tudo o que é aponta para uma “conformação de domínio", para "conformações complexas de duração de vida relativa no interior do devir". Tudo o que requisita ser, toda unidade, toda mônada, toda coisa pensável já sempre precisa surgir em sintonia com a dinâmica que traz a união da pluralidade em jogo na vontade de poder. No momento em que isso se implementa radicalmente, temos ao mesmo tempo uma transposição radical do poder antes estabelecido ao Criador (Deus) para o campo de constituição da existência humana. De alguma forma, o que tem lugar por meio da filosofia nietzschiana é a pressuposição de uma superação de uma dimensão de poder anteriormente alienada. Exatamente como o poder de criação e manutenção da realidade ${ }^{54}$ como um todo estava sob a posse de uma entidade suprema que se mostrava como o princípio e o télos da totalidade, esse poder agora é completamente transferido para o cerne do devir da vontade de poder. A sentença nietzschiana "Deus está morto" remete-nos, portanto, para o cerne de uma experiência, no interior da qual toda transcendência acaba por se dissolver

53 Cf. quanto a essa absolutização F. Nietzsche, Obra póstuma, Novembro de 1887 - Março de 1888, em Kritische Studienausgabe, op.cit., vol.13, 11 (73).

54 Segundo a teoria cristã da criação contínua, Deus não é apenas aquele que cria o mundo, mas também fundamentalmente aquele que se mostra como o responsável por sua manutenção incessante. Se Deus em único momento deixasse de querer que a realidade se apresentasse tal como se apresenta; se Ele deixasse um único momento de funcionar como causa última da realidade, tudo imediatamente desapareceria 
em nome de um movimento incessante de conformação dos fenômenos que não possui nenhum sentido para além de si mesmo. Mas o que temos aqui então?

Heidegger fala-nos no texto uma vez mais de uma certa conversão. Nós saímos de início da "subjetividade da razão incondicionada" para a "subjetividade incondicionada da vontade de poder". No primeiro caso, a incondicionalidade está ligada fundamentalmente ao projeto moderno de fundamentação da verdade do todo a partir da certeza oriunda do cogito (Descartes), de definição do espaço de pleno funcionamento da subjetividade transcendental e de circunscrição de toda objetividade ao âmbito de constituição da experiência (Kant) ou de transformação da subjetividade em princípio estruturador de realidade (Hegel). O problema dessa primeira incondicionalidade é o fato de ainda restringir a dinâmica de configuração de realidade a um elemento a priori que apresenta uma espécie de barreira extrínseca a essa dinâmica. Tal como já mencionamos algumas páginas atrás, a filosofia nietzschiana nasce justamente de uma superação de uma certa "imodéstia risível" da filosofia moderna: a imodéstia de supor que tudo é perspectivístico, menos a subjetividade pura enquanto o princípio de realização não perspectivístico de toda construção perspectivística. No momento em que se supera essa imodéstia, a incondicionalidade sai do âmbito da subjetividade representadora e passa para a própria vida do real. Essa conversão citada por Heidegger coloca tudo em termos da dinâmica mesma de uma certa vontade, do mesmo modo que impõe um movimento incessante de extensão cada vez mais radical de suas malhas de domínio. Tal como vimos anteriormente, vontade de poder não é uma expressão que descreva a saída de uma determinada instância para outra: de uma instância a priori determinada chamada vontade para uma outra instância também já constituída a priori designada poder. Ao contrário, a vontade essencializa-se aqui incessantemente como poder. No que ela se dá, ela necessariamente envolve o surgimento de uma conformação de domínio. A assunção da vontade de poder como princípio operativo em todas as configurações possíveis de realidade acaba por confundir a dinâmica de realização da vontade de poder com o próprio modo de ser do real - uma equiparação que se faz não em detrimento do devir em seu caráter soberano, mas em sintonia com a afirmação máxima de uma tal soberania. $\mathrm{Na}$ medida em que essa assunção se dá, a subjetividade incondicionada da vontade de poder articula-se com um projeto de humanidade. Dito de maneira ainda mais explícita: a subjetividade incondicionada da vontade de poder requisita para si um certo tipo de homem que tenha nascido justamente da absolutização aí em jogo. Heidegger diz isso logo em seguida no texto: 
Por si só, a subjetividade levada ao acabamento veda um fora de si mesma. Nada faz a requisição pelo ser sem se encontrar na esfera de poder da subjetividade levada ao acabamento. Mesmo o suprassensível e o âmbito de um Deus suprassensível desmoronaram. Agora é preciso que o homem, na medida em que somente ele se mostra como vontade representadora, instauradora de valores em meio ao ente como um tal na totalidade, ofereça à subjetividade levada ao acabamento os sítios de sua essência pura. Por isso, a vontade de poder como a subjetividade levada ao acabamento não pode colocar sua essência senão no sujeito em que o homem é, e, em verdade, aquele homem que está além do homem até aqui.

Mas quem é afinal o além-do-homem para Heidegger?

O texto acima deixa claro o contexto em que Heidegger insere a concepção nietzschiana do além-do-homem: o contexto da morte de Deus e da dissolução radical do supra-sensível. Segundo a leitura heideggeriana, a morte de Deus aponta efetivamente para a experiência fundamental do pensamento de Nietzsche. Contudo, o que Nietzsche entende por morte de Deus não envolve nem a negação dogmática de um ente supremo em específico, nem tampouco a exposição de uma descrença fundamental em relação à existência desse ente. Ao contrário, essa sentença descreve muito mais a assunção derradeira de um limite constitutivo do próprio conhecimento humano. A morte de Deus nasce de um aquiescimento sem travas aos limites ônticos no interior dos quais o pensamento precisa sempre se movimentar. Desse modo, a afirmação nietzschiana da morte de Deus não aponta para a exposição de uma crença ou descrença específica em relação à existência de um ente supostamente supremo, mas nos remete para a dissolução do princípio mesmo que promovia a instauração desse espaço. Ela fala-nos sobre a própria dissolução de um dos lados da dicotomia metafísica fundamental, a dicotomia entre mundo sensível e mundo supra-sensível. Ela designa, em outras palavras, a supressão radical do suprassensível tomado como dimensão autônoma e como o fundamento indispensável para a consistência ontológica do sensível. Dessa dissolução descortinam-se um novo destino e toda uma nova gama de possibilidades para o homem ocidental. Desonerado de uma transcendência que funcionava a priori como uma proveniência perfeita em relação à qual a vida mesma não se mostrava senão como decadência e que fornecia originariamente uma meta estrutural para a existência, o ho- 
mem parece poder conquistar pela primeira vez plenamente a sua humanidade. No entanto, essa conquista não se perfaz a partir de uma simples negação dogmática do suprassensível e de uma subsequente conformação do existir a partir da paixão inerente a toda negação ${ }^{55}$. Ao contrário, a conquista pelo homem de sua própria humanidade se dá muito mais pela transformação da transcendência em mero construto do mundo sensível, em uma espécie de produção de imagens duplicadas perfeitas a partir de uma certa má interpretação do próprio processo de gênese dessas imagens. É exatamente isso que nos diz uma anotação nietzschiana datada entre novembro de 1887 e março de 1888: "Como quer que tenha sido concebido até aqui, o 'mundo verdadeiro' sempre foi o mundo aparente ainda uma vez mais". ${ }^{56}$ Essa transformação acima mencionada promove um tal conquista por parte do homem, porque ela entrega uma vez mais uma dimensão constitutiva de sua existência que ele tinha alienado de si em função de uma necessidade de venerar algo superior a ele mesmo ${ }^{57}$. O homem conquista assim para Nietzsche plenamente a sua humanidade no momento em que supera o próprio processo de alienação de uma das partes mais constitutivas de sua existência e descobre o além como uma dimensão intrínseca a ele mesmo. O homem oriundo da experiência decisiva da morte de Deus é, com isso, um homem que cunhou um novo modo de relação com o supra-sensível, com o além. Nietzsche o denomina, então, coerentemente, o além-do-homem (Über-mensch). Não porque ele seja mais do que o homem até então (como a tradução até bem pouco tempo corrente de Übermensch por super-homem dava a entender), mas porque ele integra a transcendência à sua dinâmica de realização. Todavia, uma tal integração implica uma radical articulação dos modos de ser de realidade com as possibilidades mesmas de estruturação da existência humana (perspectivas) e com a vontade de poder como princípio de determinação dessas diversas possibilidades. Nos próprios termos nietzschianos:

Atravessa meus escritos o fato de o valor do mundo residir em nossa interpretação ( - de talvez em algum lugar ainda serem possíveis outras interpretações além das meramente humanas), de as interpretações até aqui

55 Cf. quanto a esse ponto F.Nietzsche, Gaia ciência, em Kritische Studienausgabe, op.cit., vol. 3, pp. 346, 579-580.

56 F.Nietzsche, Obra póstuma, Novembro de 1887-Março de 1888, em Kritische $\quad$ Studienausgabe, op.cit., vol.13, 11(50).

57 Cf., quanto a esse ponto, o meu escrito "A religião da terra: o lugar do sagrado no pensamento de Friedrich Nietzsche", em M.A.Barrenechea; C.Feitosa; P.Pinheiro, (orgs.) Fidelidade à Terra, Assim Falou Nietzsche IV, Rio de Janeiro, Faperj; Unirio; DP\&A, 2003. 
serem avaliações perspectivísticas, em virtude das quais nós nos mantemos na vida, isso é, na vontade de poder, para o crescimento do poder, de toda elevação do homem trazer consigo a superação de interpretações mais estreitas, de todo e qualquer fortalecimento ou ampliação do poder abrir novas perspectivas e conclamar à crença em novos horizonte. O mundo que nos concerne de algum modo é falso, ou seja, não é nenhum fato, mas uma sedimentação e um arredondamento feito sobre uma soma mais reduzida de observações; ele está 'em fluxo', como algo que devém, como uma falsidade que sempre se translada novamente, que nunca se aproxima da verdade: pois - não há nenhuma 'verdade' ${ }^{58}$

Nesse sentido, a humanidade do além-do-homem aponta para a sua completa circunscrição ao processo de configuração da subjetividade incondicionada da vontade de poder. Como essa circunscrição confunde-se com a dinâmica de realização mesma do mundo da técnica, a humanidade do além-do-homem não é senão a humanidade tocada pela requisição originária da técnica para que o todo se transforme em fundo de reserva. Exatamente isso revela o além-do-homem como o homem radicalmente absorvido na composição técnica. Esse homem não é, por sua vez, senão o homem determinado pela tonalidade afetiva fundamental do tédio, não é senão o homem entediado. Mas o que nos leva afinal a sustentar uma tal afirmação? O homem contemporâneo não é muito mais o homem super-acelerado? Peguntemos, então, uma vez mais: qual a ligação entre tédio e técnica?

Tal como tivemos a oportunidade de acompanhar anteriormente, a transformação da vontade de poder em princípio operativo no universo da técnica ${ }^{59}$ acaba por provocar uma radical absorção do homem na dinâmica de realização da vontade de vontade. Na medida mesmo em que o homem se articula com o posicionamento total da natureza como fundo de reserva e com a vontade de poder como princípio de estruturação desse posicionamento, ele vai paulatinamente se inserindo sem travas nos desdobramentos da essência da técnica e se transformando também em fundo de reserva para a vontade autonomizada. Essa autonomização da vontade aponta para uma absolutização radical dos processos ônticos em geral, o que traz consigo a instauração de um novo ritmo para

58 F.Nietzsche, Obra póstuma, Outono de 1885 -Outono de 1886, em Kritische dienausgabe, op.cit., vol.12, 2 (108), p. 114.

59 F.Nietzsche, Obra póstuma, Outono de 1885 - Outono de 1886, em Kritische dienausgabe, op.cit., vol.12, 2 (108), p. 114.

Stu-

Stu- 
a existência como um todo. Tudo se resume agora às possibilidades ônticas de configuração que se sucedem incessantemente e o elemento ontológico vem à tona como uma mera duplicação alienada do ôntico. Porquanto o ôntico é aqui marcado pela formação incessante de configurações volitivas de poder que sempre precisam se lançar para além de si mesmas, ele nunca encontra um campo de jogo realmente estável para o seu estabelecimento e se vê entregue a um movimento incessante de transformação, de simples extensão de suas malhas de poder. Reina, assim, uma experiência originária de soberania do devir. Portanto, o desvelamento do ente na totalidade como fundo de reserva tem por consequência a conversão primordial do homem em função dos elementos em jogo no devir, em conformação particular da vontade de vontade. No momento em que essa conversão se dá, o homem perde radicalmente a sua relação com o ser e passa a se realizar exclusivamente a partir de conjunturas existenciárias. Não que ele perca totalmente o contato com a compreensão de ser como a instância responsável pela determinação de uma medida para todos os comportamentos possíveis em relação ao ente e a si próprio - o ser-aí nunca pode experimentar efetivamente uma tal perda e continuar sendo o que e como ele é. Ao contrário, o que acontece é muito mais um afastamento ante o próprio horizonte de constituição da compreensão de ser e a imersão imediata no espaço aberto por uma compreensão já sedimentada. Dessa forma, deparamo-nos aqui com a seguinte situação. O homem contemporâneo em sua ressonância de fundo com o mundo da técnica não perfaz a sua existência senão a partir de um exílio em relação ao ser que se retraiu completamente e só se mostra agora como o nada vazio de determinações. Esse exílio o articula com a velocidade vertiginosa do devir autônomo das configurações ônticas desprovidas de qualquer peso ontológico e tudo ganha uma aparência de dinamicidade, de alteridades e fluxos se expandindo em profusão. No entanto, a aparência ora em questão nasce diretamente de uma volatilização do todo. Tudo parece tão diverso, porque nada mais desdobra em seu campo existencial a sua diferencialidade específica. Nada mais: nem os entes, nem os seres-aí. Desvinculado de sua ligação originária com o ser, o ser-aí também se aparta simultaneamente de si próprio como o ente que já sempre se movimento no interior de uma tal ligação. E é exatamente dessa perda de si próprio que emerge então a tonalidade afetiva do tédio.

Na medida em que o si próprio se vê engolido pelo abismo de infinitas possibilidades se sucedendo em uma velocidade vertiginosa, os homens vivenciam uma inexorável auto-dissolução de suas singularidades específicas e perdem ao mesmo tempo toda determinação ontológica. Em meio à perda de contato com a verdade do ser e à subsequente vigência soberania do devir não me encontro 
mais em condições de responder verdadeiramente à pergunta por meu ser mais próprio. A fim de que seja interessante para mim mesmo, no entanto, é antes de tudo necessário que consiga apresentar uma tal resposta. Sem a presença de um si próprio que se constitui por meio do movimento de realização das ações, a superação da dispersão agradável na multiplicidade traz consigo incessantemente uma experiência insuportável de vazio. Essa experiência inviabiliza qualquer interesse por mim mesmo e me lança em um desconforto primordial frente a mim mesmo. Se analisarmos agora a consistência deste desinteresse e deste desconforto, não será difícil alcançar então a denominação mais adequada para a disposição aí dominante. Tédio é justamente o termo que não designa em seu sentido mais próprio apenas o estado de coisas em que nos sentimos presos a uma situação em si mesma vazia de sentido, mas também e principalmente em que o vazio se mostra como estando radicalmente ligado a nós mesmos. Não são somente as coisas que são entendiantes, mas o tédio das coisas é normalmente o reflexo de nosso tédio fundamental ${ }^{60}$. Desse modo, o tédio é uma tonalidade afetiva fundamental do homem na era da técnica, porque o tédio sempre nasce necessariamente da perda de si próprio. O tédio está, em suma, na raiz existencial do homem contemporâneo, do projeto originário de sua realização. O tédio é o tema de nosso tempo.

60 É por um lado inegável que situações podem ser em si mesmas entediantes. Festas, programas, reuniões sociais são muitas vezes marcados pela ausência de qualquer animação e são outras tantas vezes um martírio para muitos dos presentes. É por outro lado porém igualmente inegável que nestas situações o tédio não chega até nós de maneira totalmente extrínseca. Mesmo aí o tédio provém de uma relação inerente à constituição do si próprio e é esta constituição que precisa ser originariamente considerada.

BIRAULT, Henri. Heidegger et l'expérience de la pensée. Paris: PUF, 1978.

CASANOVA, Marco Antonio. $O$ instante extraordinário: vida, história e valor na obra de Friedrich Nietzsche. Rio de Janeiro: Forense Universitária, 2003.

\section{A linguagem do acontecimento}

apropriativo. In: Revista Natureza Humana. Volume 4, Fascículo 2, Série 2002, pp. 315-343.

- Nada a caminho : impessoalidade, niilismo e técnica no pensamento de Martin Heidegger. Rio de Janeiro: Forense Universitária, 2006.
DALLMAYR, F. Heidegger on Macht and Machenschaft. In: Continental Philosophy Review, 34, 3, September 2001, pp. 247-267.

DENKER, Albert et allii (org.). Heigegger Jahrbuch: Heidegger und Nietzsche. Freiburg/ Munique: Alber, 2005.

DREYFUS, Hubert. Being-in-the-world: A commentary on Heidegger's Being and Time, Division I. California: California University Press, 1990. 
- Between Techné and Technology. The

ambiguous place of equipment in BT, in: H. Dreyfus/H.Hall:

Heidegger: A critical reader, Oxford: Oxford University Press, 1992.

FERRY, Luc e RENAULT, Alain. Heidegger et les modernes. Paris : Le livre du poche, 2001.

FRANK, Didier. Nietzsche et l'ombre de Dieu. Paris: PUF, 1998.

GLAZEBROOK, Trish. From physis to Nature, techne to Technology: Heidegger on Aristotle, Galileo and Newton. In: The southern journal of philosophy, XXXVIII, 2000, pp. 225-248.

HAAR, Michel. Heidegger et le surhomme. In: Revue de l'enseignement philosophique XXX, 3, FebruarMärz, 1980, pp. 1-17.

. The end of distress: the end of technology? In: Research in Phenomenology XIII, 1983, pp. 43-63.

HEIDEGGER, Martin. Gesamtausgabe 2, 6.1 e 6.2, 9, 41, 45, 55, 65, 66, 67 e 75. Frankfurt am Main: Vittorio Klostermann, 1991-2002.

JANICAUD, D./ J.-F. Mattéi. La métaphysique à la limite. Paris : PUF, 1983.

LOVITT, William/ LOVITT, Harriet Brundage. Modern Technology in the Heideggerian Perspective. California: California University Press, 1995.

MARGREITER, R/ Leidlmair, K. Heidegger. Technik Ethik - Politik. Würzburg: Universitätsverlag Winter, 1997.

MÜLLER-LAUTER, W. Möglichkeit und Wirklichkeit bei Martin Heidegger. Berlin: De Gruyther, 1970.
. Das Willenswesen und der Übermensch.

Ein Beitrag zu Heideggers Nietzsche-Interpretationen. In: Nietzsche Studien V, pp. 132-191.

. Nietzsches Lehre vom Willen zur Macht. In:

Nietzsche Studien III, pp. 1-60.

. Nietzsche Interpretationen III: Nietzsche und Heidegger. Berlin: De Gruyther, 2000.

NUNES, Benedito. Passagem para o poético. Filosofia e poesia em Heidegger. São Paulo: Ática, 1986. . Crivo de papel. São Paulo: Ática, 1999. Hermenêutica e poesia. Belo Horizonte:

UFMG, 1999

- O Nietzsche de Heidegger. Rio de Janeiro: Pazulin, 2000.

SALLIS, John. ECHOES after Heidegger. Bloomington and Indianapolis: Indiana Un University Press, 1990. . Delimitations (Phenomenology and the End of Metaphysics). Second Edition. Bloomington and Indianapolis: Indiana University Press, 1995.

SEUBOLD, Günter. Heideggers Analyse der neuzeitlichen Technik. Freiburg/ Munique: Alber, 1986.

ZARADER, Marlène. Heidegger et les paroles d'origine. Paris : Vrin, 1990.

ZIMMERMAN, Michael. Heidegger's confrontation with modern technology, politics and art. Indiana: Indiana University Press, 1999.

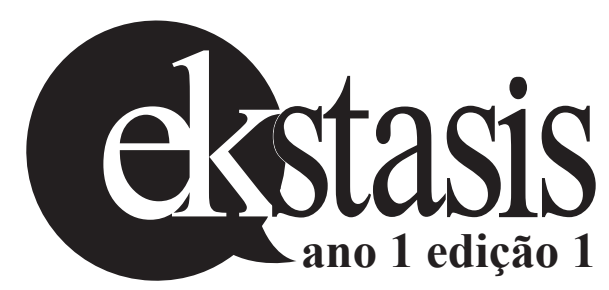

